\title{
The search for efficient electrocatalysts as counter electrode materials for dye-sensitized solar cells: mechanistic study, material screening and experimental validation
}

\author{
Lulu Wang ${ }^{1,5}$, Mohammad Al-Mamun ${ }^{1,5}$, Porun Liu ${ }^{1}$, Yun Wang ${ }^{1}$, Hua Gui Yang ${ }^{1,2}$, \\ Hai Feng Wang ${ }^{3}$ and Huijun Zhao ${ }^{1,4}$
}

In recent years, there has been a significant increase in the studies on effective energy-conversion devices, including photovoltaics and fuel cells, which aim to alleviate the enormous energy demand, as well as the environmental pollution issues associated with current power consumption. Among these devices, dye-sensitized solar cells (DSCs) have received significant attention owing to their simple fabrication procedure, cost-effectiveness and high-power-conversion efficiency. The counter electrode (CE) of the DSCs is an important component and generally uses platinum as its benchmark material, the high cost and scarcity of which have limited the broad application of the DSCs. Thus, substantial effort has been devoted to seek active CE materials with low cost, high electrocatalytic activity and excellent stability. Nevertheless, this is generally achieved via a 'trial-and-error' method owing to the lack of information on the mechanism of the electrocatalytic reaction on the CE's surface. This report summarizes the recent advances in the mechanistic study of the interfacial electrocatalytic reaction on CE materials, as well as the establishment of a rational screening protocol for efficient CE materials. Furthermore, several outstanding CE materials developed via this protocol have been reviewed. The demonstrated combined approach can be extended to the studies of other essential electrocatalytic reactions.

NPG Asia Materials (2015) 7, e226; doi:10.1038/am.2015.121; published online 20 November 2015

\section{INTRODUCTION}

The global demand for energy has significantly increased, and this trend is predicted to continue in the future. Solar energy, which is one of the most abundant and least-utilized clean energy sources, demonstrates great potential to satisfy the future global energy consumption. A photovoltaic (PV) system or solar cell, which directly converts sunlight into electricity, has attracted significant attention in the academic and industrial fields. Although the current PV market is dominated by silicon-based solar cells, several studies have been performed to develop new-generation solar cells with a higher efficiency and a lower price. Among them, dye-sensitized solar cells (DSCs) exhibit a promising future owing to their ease of fabrication, low-cost and high sunlight-harvesting efficiency. ${ }^{1-4}$ In typical single $\mathrm{p}-\mathrm{n}$ junction $\mathrm{PV}$ devices, semiconducting materials are used to generate, separate and transport charge carriers (electrons and holes) to transmit electricity under solar illumination. However, in the DSCs, photoelectrons are generated by separate photosensitive dyes and transported using semiconducting materials. The unique charge separation and injection processes lead to a relatively lowrecombination rate compared with that of traditional solar cells. In addition, the DSCs can be fabricated using inexpensive and earthabundant materials into different shapes, colors and transparencies with a high efficiency under both high or low light intensity. ${ }^{5}$ Significant progress has been achieved in improving the powerconversion efficiency (PCE) and operation stability. ${ }^{6}$ Recently, the DSCs have achieved a PCE of $12.3 \%$ in laboratory experiments, ${ }^{7}$ which indicates a great potential as new-generation PV devices for renewable energy sources in the future.

Generally, a DSC has a sandwich structure consisting of a dye-sensitized mesoporous nanocrystalline semiconductor photoanode, an electrolyte containing a redox couple and a counter electrode (CE). A schematic diagram of a typical DSC construction along with its major electron pathways is illustrated in Figure 1. An electrocatalyst-coated CE used for redox couple regeneration after

${ }^{1}$ Centre for Clean Environment and Energy, Griffith University, Gold Coast, QLD, Australia; ${ }^{2}$ Key Laboratory for Ultrafine Materials of Ministry of Education, School of Materials Science and Engineering, East China University of Science and Technology, Shanghai, China; ${ }^{3}$ Key Laboratory for Advanced Materials, Centre for Computational Chemistry and Research Institute of Industrial Catalysis, East China University of Science and Technology, Shanghai, China and ${ }^{4}$ Centre for Environmental and Energy Nanomaterials, Institute of Solid State Physics, Chinese Academy of Sciences, Hefei, China

5These authors contributed equally to this work.

Correspondence: Professor H Zhao, Centre for Clean Environment and Energy, Griffith University, Gold Coast Campus, Gold Coast, QLD 4222, Australia.

E-mail: h.zhao@griffith.edu.au

Received 23 May 2015; revised 11 July 2015; accepted 22 July 2015 


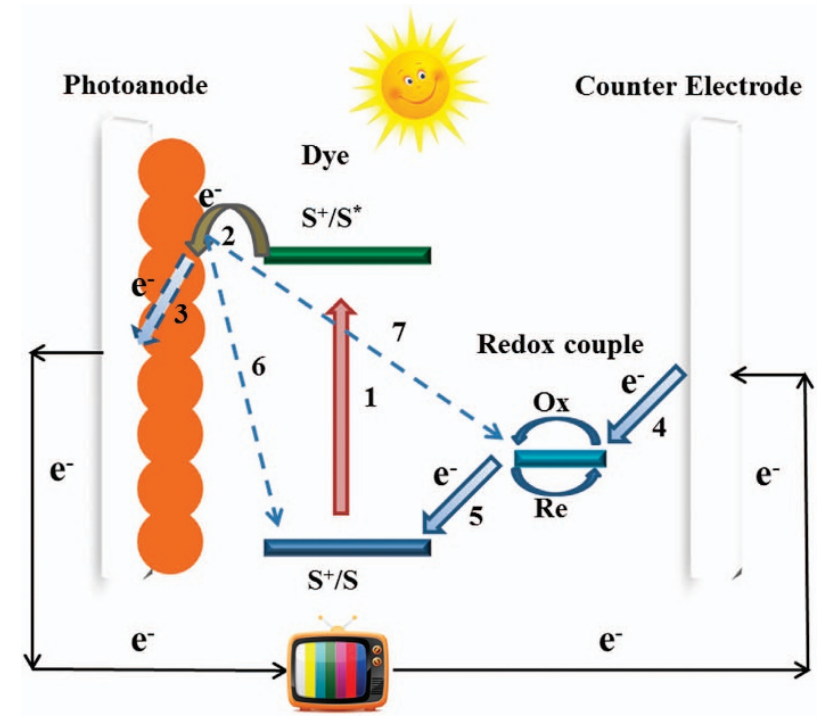

Figure 1 Schematic diagram of a typical DSC construction along with the major electron pathways.

electron injection is one of the most crucial components in the DSCs. ${ }^{8-15}$ Platinum (Pt) has been used as a benchmark CE material because of its excellent catalytic activity and high conductivity. Nevertheless, its drawbacks, such as high cost and scarcity, strongly hinder the broad application of Pt in the DSCs. Thus, to overcome this challenge, several inexpensive Pt-free catalytic alternatives with outstanding electrocatalytic activity and electrical conductivity, for example, inorganic semiconductor, ${ }^{16-19}$ carbon, ${ }^{20,21}$ conductive polymers $^{22,23}$ and hybrid materials, ${ }^{24,25}$ have been developed. However, most CE materials have been discovered using the 'trial-anderror' methodology owing to the lack of information on the electrocatalytic reaction at the solution/CE material interface. In early 2013, a breakthrough has been made in this field: a general screening strategy for high-efficient CE materials has been successfully established based on the first-principles calculations, ${ }^{26}$ and numerous new CE materials have been thus developed via this protocol. In this report, we first summarize the recent advances in the mechanistic study via theoretical calculations for a triiodide reduction reaction (widely used redox couple in DSCs) on a CE surface. Then, to confirm the as-developed screening strategy based on the mechanistic study, we highlight various high-performance Pt-free CE materials, such as metals, metal oxides, metal sulfides, metal nitrides and metal carbides. Finally, conclusions and perspectives are provided to illustrate the opportunities, as well as challenges in this field.

\section{WORKING PRINCIPLES AND KEY COMPONENTS OF DSCS}

Generally, the working principle of the DSCs involves several elementary processes (Figure 1). Under solar illumination, the adsorbed dye molecule is promoted to the excited state (process 1), photogenerated electrons are injected into the conduction band of the photoanode materials (semiconductors) and the molecule is transitioned into its oxidized state (process 2). The injected electrons will then be collected by the photoanode substrate (process 3 ), transferred from the outer circuit and used to reduce the oxidized redox mediator on the CE's surface (process 4 ). The entire electron transfer cycle will be finished when the oxidized dye molecule is reduced to its ground state by the redox mediator in the electrolyte (process 5). Recombination processes, including the injected electron recombined with the oxidized dye molecule and/or the oxidized redox mediator (processes 6 and 7), may also occur during this cycle.

Since the development of the initial DSC by Grätzel et al. in 1991, various optimized DSC components have been developed to achieve a high PCE and improved operation stability. Thus far, thousands of dyes (sensitizers) have been investigated to achieve an efficient light absorption. ${ }^{27,28}$ The most widely applied sensitizers are $\mathrm{Ru}(\mathrm{II})$ - polypyridyl complexes, such as dye N3 and N719. ${ }^{29}$ Furthermore, substantial effort has been devoted to the development of new semiconductors for the photoanodes of the DSCs, such as $\mathrm{SnO}_{2},{ }^{30}$ $\mathrm{ZnO}^{31}$ and $\mathrm{Nb}_{2} \mathrm{O}_{5}{ }^{32}$ Furthermore, mesoporous $\mathrm{TiO}_{2}$ is still the preferred choice in the DSCs owing to its large band gap and highconduction band energy. ${ }^{3}$ Moreover, the electrolyte is another critical part of the DSCs. A prompt and non-interrupted electron supply is the basic requirement needed to regenerate the dye sensitizer for a redox couple in the electrolyte. Generally, the electrolytes used in the DSCs can be divided into three categories: liquid electrolytes, ${ }^{33}$ quasi-solid electrolytes ${ }^{34}$ and solid-state hole conductors. ${ }^{35}$ Among them, liquid electrolyte is generally used, and several different redox couples have been reported, such as the Co-complex $(\mathrm{Co}(I I) / C o(I I I)),{ }^{36}$ disulfide/ thiolate $\left(T^{-} / T_{2}\right),{ }^{37}$ ferrocene/ferrocenium $\left(F c / F c^{+}\right),{ }^{38} \mathrm{Cu}(I) / C u(I I)^{39}$ and $N i(I I I) / N i(I V) .{ }^{40}$ Thus far, the iodide/triiodide $\left(I^{-} / I_{3}^{-}\right)$redox couple in an organic solvent (normally $\mathrm{CH}_{3} \mathrm{CN}$ ) is the most preferred and commonly used redox couple because of its high solubility and ionic mobility. The rapid kinetics of electron donation (for dye regeneration by $I^{-}$) and the extremely slow recombination (between electrons in the photoanode and $I_{3}^{-}$in the electrolyte) leads to a high PCE of the DSC compared with that of the other redox couples investigated. Moreover, the $I^{-} / I_{3}^{-}$redox couple exhibits an outstanding stability during the long run of the DSCs. ${ }^{41}$ After $I^{-}$regenerates the dye sensitizer (by donating one electron) and evolves into $I_{3}^{-}$, it is important to rapidly reduce $I_{3}^{-}$to $I^{-}$. The region where the triiodide reduction reaction occurs is the solid-liquid interface between the electrolyte and the CE of the DSC. The CE here has a dual role: providing a prompt electron transport from the outer circuit and ensuring a rapid $I_{3}^{-}$to $I^{-}$conversion process. Therefore, a good conductivity and high electrocatalytic activity toward the triiodide reduction reaction are the basic requirements for the CE materials. Herein, the report only concentrates on the development of efficient CE materials for the triiodide reduction reaction. Reviews on DSCs with other redox couples are available elsewhere. ${ }^{5,42,43}$

\section{BASIC THEORY OF RATIONAL SCREENING STRATEGY FOR CE MATERIALS}

To date, a large number of efficient CE materials have been developed for the triiodide reduction reaction; however, most of them are based on a 'trial-and-error' approach. Thus, an effective combinational screening approach is highly necessary to reduce the research and development cost and cycle. The computational approach is regarded as an efficient, high-throughput alternative. ${ }^{44}$ As one of the most effective and accurate computational methods, the density functional theory (DFT) has been widely applied to analyze the catalytic mechanism in several different heterogeneous catalytic processes, such as oxygen reduction reaction ${ }^{45,46}$ and hydrogen evolution reaction. ${ }^{47}$ Recently, a DFT modeling method has been introduced to the DSCs field. ${ }^{48-50}$ Specifically, it can be applied to explore the fundamental processes in the electrocatalysis reaction and understand the characteristics of fabricated CEs in the DSCs systems, which is beneficial in discovering the weak points in the designing stage and assisting in discovering molecularly designed CE materials with more optimized 
solutions. Using the first-principles calculations, our research group has explored the key parameter affecting the electrocatalytic efficiency and developed a general and efficient screening framework for the electrocatalytic activity of potential CE materials.

\section{Electrocatalytic activity origin of CE electrocatalysts}

The overall triiodide reduction reaction occurring on the $\mathrm{CE}$ can be described as follows:

$$
I_{3}^{-}(\mathrm{sol})+2 e^{-}=3 I^{-}(\mathrm{sol})
$$

This reaction can be divided into three detailed steps:

$$
\begin{aligned}
& I_{3}^{-}(\mathrm{sol}) \leftrightarrow I_{2}(\mathrm{sol})+I^{-}(\mathrm{sol}) \\
& I_{2}(\mathrm{sol})+2^{*} \rightarrow 2 I^{*} \\
& I^{*}+e^{-} \rightarrow I^{-}(\mathrm{sol})
\end{aligned}
$$

where '*' represents the free site on the electrode surface; and 'sol' indicates the solution (generally $\mathrm{CH}_{3} \mathrm{CN}$ ). The solution reaction, reaction step (2), has been verified to be typically fast and in equilibrium. ${ }^{51}$ Therefore, the overall catalytic activity can be determined by the iodine reduction reaction (IRR) as follows:

$$
I_{2}+2 e^{-} \rightarrow 2 I^{-}
$$

which occurs at the liquid-solid interface, that is, the dissociative adsorption of one iodine molecule onto the CE's surface to form two surface iodine atoms (reaction step (3)), and the removal of one electron from each adsorbed iodine atom to produce solvated iodides (reaction step (4)).

To identify the key parameter affecting the entire IRR process, a two-step model, which has been reported previously by Wang et al., ${ }^{52,53}$ was applied to illustrate the heterogeneous catalytic reactions, that is, the adsorption of the reactants to form intermediates and the desorption of the intermediates to form products. The energy profile involved in these two steps is provided in Figure 2a. Two important parameters, that is, the $I_{2}$ dissociation barrier $\left(E_{\mathrm{a}}^{\mathrm{dis}}\right)$ and the $I^{*}$ desorption barrier $\left(E_{\mathrm{a}}^{\mathrm{des}}\right)$, were used to determine the thermodynamics of the IRR process. ${ }^{26}$

According to the Bronsted-Evans-Polanyi relation of dissociative adsorption, ${ }^{53}$ one can obtain the expression as follows:

$$
E_{\mathrm{a}}^{\mathrm{dis}}=\alpha_{1} E_{\mathrm{ad}}^{\mathrm{I}}+\beta_{1}, \alpha_{1}<0
$$

where $E_{\text {ad }}^{\mathrm{I}}$ is the adsorption energies of the I atom on the surface of the electrodes. Because the $\mathrm{CH}_{3} \mathrm{CN}$ solvent molecule has a relatively strong adsorption energy on the electrode's surface, a competitive adsorption effect exists between the $\mathrm{I}$ atoms and the $\mathrm{CH}_{3} \mathrm{CN}$ molecules when the I atoms are introduced onto the electrode's surface. Therefore, $E_{\text {ad }}^{\mathrm{I}}$ can be defined as follows:

$$
E_{\mathrm{ad}}^{\mathrm{I}}=E(\text { interface })+1 / 2 E\left(I_{2}\right)-E(I / \text { interface })
$$

where $E$ (interface), $E\left(I_{2}\right)$ and $E(I /$ interface) represent the energies of the liquid/electrode interface, $I_{2}$ in the gas phase and the liquid/electrode interface with the adsorbed I atoms, respectively.

When considering the desorption process, the desorption barrier generally becomes higher as its binding strength with the electrocatalyst surface increases. A linear relationship between $E_{\mathrm{a}}^{\mathrm{dis}}$ and $E_{\mathrm{ad}}^{\mathrm{I}}$ was revealed, which can be given as follows:

$$
E_{\mathrm{a}}^{\mathrm{des}}=\alpha_{2} E_{\mathrm{ad}}^{\mathrm{I}}+\beta_{2}, \alpha_{2}>0
$$

In equations (6) and (8), $\alpha_{1}, \alpha_{2}, \beta_{1}$ and $\beta_{2}$ are constants. Clearly, both the $I_{2}$ dissociation barrier and the $I^{*}$ desorption barrier are related to the adsorption energy of $I$ : $E_{\mathrm{a}}^{\mathrm{dis}}$ has a negative linear correlation with
$E_{\text {ad }}^{\mathrm{I}}$ whereas $E_{\mathrm{a}}^{\mathrm{des}}$ increases linearly as $E_{\mathrm{ad}}^{\mathrm{I}}$ increases. These two linear relationships demonstrate that the $E_{\mathrm{ad}}^{\mathrm{I}}$ on the CE material's surfaces has a crucial role in determining the overall catalytic activity of the IRR. In other words, the $E_{\text {ad }}^{\mathrm{I}}$ can serve as a good descriptor for the IRR activity. When $E_{\text {ad }}^{\mathrm{I}}$ is too large, the removal of $I$ to form $I^{-}$will be difficult, and the overall activity of desorption is limited. If $E_{\mathrm{ad}}^{\mathrm{I}}$ is weak, the $I_{2}$ dissociation step will be hindered.

Using a microkinetic analysis, further quantitative discussions were performed by estimating the turnover frequency (TOF) of the twostep IRR under steady-state conditions. Within the microkinetic framework, the reaction rate of steps (3) and (4) can be written as follows:

$$
\begin{aligned}
& r_{1}=k_{1} c_{I_{2}} \theta^{2}\left(1-Z_{1}\right) \\
& r_{2}=k_{2} \theta_{I^{*}}\left(1-Z_{2}\right)
\end{aligned}
$$

where $\theta$ and $\theta_{I^{*}}$ are the coverage of the surface-free site and the I atom, respectively; $c_{I_{2}}$ is the concentration of the $I_{2}$ molecule in the solution; $Z_{1}$ and $Z_{2}$ are the reaction reversibility of steps (3) and (4), respectively; and $k_{1}$ and $k_{2}$ are the rate constants of reactions (3) and (4), respectively, which can be determined using the transition-state
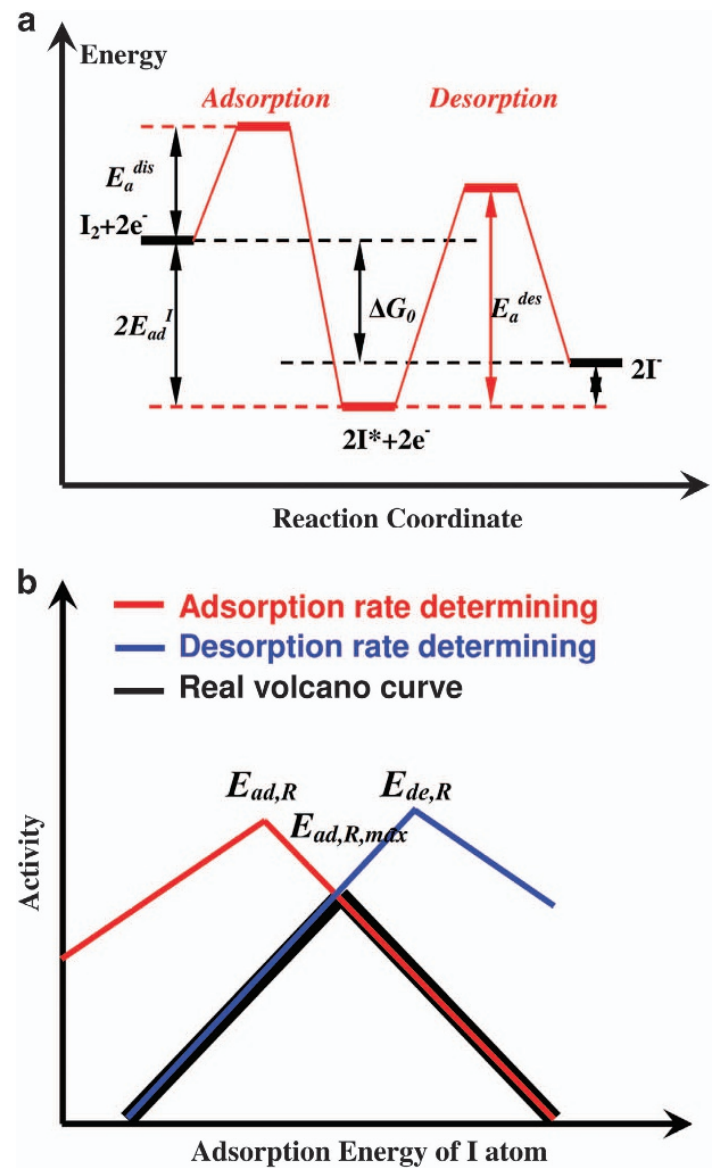

Figure 2 (a) Schematic energy profile of a two-step model considering the dissociative adsorption of reactants and associative desorption of products on a catalyst surface. (b) Schematic diagram of the variation in activity (black volcano curve) as a function of the adsorption energy of the I atom. The adsorption (red) and desorption (blue) are rate-determining processes. Adapted from Hou et al. ${ }^{26}$ Copyright $\odot 2013$ Rights Managed by Nature Publishing Group. 
theory as follows:

$$
K_{i}=\frac{K_{B} T}{h} \exp \left(\frac{\Delta S}{R}\right) \exp \left(-\frac{E_{a}}{R T}\right)
$$

where $K_{B}$ and $h$ are constants; and $T$ is the reaction temperature.

At steady state $\left(\mathrm{TOF}=2 r_{1}=r_{2}\right)$, by applying the condition $\theta+\theta_{I^{*}}=1$, we can solve the reaction TOF numerically.

Analytically, considering the relationships of (6) and (8), it is evident that the TOF of the entire reaction can primarily be determined using $E_{\text {ad }}^{\mathrm{I}}$.

If adsorption is the rate-determining step $\left(Z_{2}=1, Z_{1}=Z_{\text {tot }}^{2}\right)$, we can obtain the expression as follows:

$$
T O F_{1}=k_{1} c_{I_{2}} \frac{K_{e q 2}^{2}}{\left(c_{I^{-}}+K_{e q 2}\right)^{2}}\left(1-Z_{t o t}^{2}\right)
$$

If desorption is the rate-determining step $\left(Z_{1}=1, Z_{2}=Z_{\text {tot }}\right)$, we can obtain the expression as follows:

$$
\mathrm{TOF}_{2}=k_{2} \frac{c_{I_{2}}^{1 / 2} K_{e q 1}^{1 / 2}}{1+c_{I_{2}}^{1 / 2} K_{e q 1}^{1 / 2}}\left(1-Z_{t o t}\right)
$$

where $K_{e q 1}$ and $K_{\text {eq } 2}$ are the reaction equilibrium constants of steps (3) and (4), respectively.

In actuality, the TOF would be determined using $\mathrm{TOF}=\mathrm{min}$ $\left\{\mathrm{TOF}_{1}, \mathrm{TOF}_{2}\right\}$ (Figure $2 \mathrm{~b}$ ), which indicates that $E_{\mathrm{ad}}^{\mathrm{I}}$ is a key parameter used to determine the complete catalytic activity.

\section{Establishment of screening framework for CE materials}

The identification of the decisive parameter of the electrocatalytic activity, that is, $E_{\text {ad }}^{\mathrm{I}}$, is followed by the determination of a suitable energy range of $E_{\text {ad }}^{\mathrm{I}}$ for the IRR. For a multistep reaction system, the Gibbs free-energy should be negative to ensure that the overall reaction proceeds in the forward direction. With respect to the IRR, the total Gibbs free-energy change $\Delta G_{0}$ provides the thermodynamic driving force as follows:

$$
\Delta G_{0}=\left(\mu_{I_{2}(\mathrm{sol})}+2 \mu_{e}\right)-2 \mu_{I^{-}(\mathrm{sol})}
$$

It is difficult to directly calculate the energy of the charged periodic system accurately. However, because we know that the Gibbs freeenergy change of the standard hydrogen electrode (SHE) reaction is zero, that is,

$$
1 / 2 H_{2(\mathrm{gas})} \leftrightarrow H_{\mathrm{aq}}^{+}+e^{-}(S H E)
$$

Then, we can obtain the reaction when combining reactions (4) and (15) as follows:

$$
I_{2(\mathrm{sol})}+H_{2(\mathrm{gas})} \rightarrow 2 I_{(\mathrm{sol})}^{-}+2 \mathrm{H}_{(\mathrm{aq})}^{+}+2 e U
$$

where $e U$ represents the electron free-energy shift in the $\mathrm{CE}$ at the voltage $\mathrm{U}$ relative to the SHE. Clearly, the Gibbs free-energy change $\Delta G_{1}$ of reaction (16) is the same as the $\Delta G_{0}$ of the IRR. Thus, based on Hess's Law, we can design a thermodynamic cycle to calculate $\Delta G_{1}$ indirectly as follows:

$$
\begin{array}{ccc}
I_{2(\mathrm{sol})}+H_{2(\mathrm{gas})} & \stackrel{\Delta G_{1}}{\rightarrow} & 2 I_{(\mathrm{sol})}^{-}+H_{(\mathrm{aq})}^{+}+2 e U \\
\downarrow-\Delta \mu_{I_{2}} & & \uparrow 2\left(E_{\mathrm{sol}}^{I^{-}}+E_{\mathrm{sol}}^{H^{+}}\right) \\
I_{2 \text { (gas) }}+H_{2(\mathrm{gas})} & \stackrel{\Delta G_{2}}{\rightarrow} & 2 I_{(\mathrm{gas})}^{-}+2 H_{(\mathrm{gas})}^{+}+2 e U
\end{array}
$$

Clearly, for the above cycle, $\Delta G_{1}=\Delta G_{2}+2\left(E_{\text {sol }}^{I^{-}}+E_{\text {sol }}^{H^{+}}\right)-\Delta \mu_{I_{2}}$. We used the Gaussian 03 software (Gaussian, Wallingford, CT, USA) to calculate $\Delta G_{2}$. The salvation energies of $I^{-}$in the $\mathrm{CH}_{3} \mathrm{CN}$ solvent
$\left(E_{\mathrm{sol}}^{I^{-}}\right)$and $\mathrm{H}^{+}$in the water $\left(E_{\mathrm{sol}}^{H^{+}}\right)$use experimental values, that is -2.86 and $-11.53 \mathrm{eV}$, respectively. ${ }^{54,55}$ The chemical potential difference of the $I_{2}$ molecule between the gas phase and the $\mathrm{CH}_{3} \mathrm{CN}$ solvent $\left(-\Delta \mu_{I_{2}}\right)$ can be calculated according to the ideal solution model by considering the phase equilibrium at the gas/liquid interface during the dissolution of $I_{2}$ as follows:

$$
\Delta \mu_{I_{2}}=\mu_{I(\text { sol })}^{0}-\mu_{I_{2}(\text { gas })}^{0}=R T \ln \frac{p_{I_{2}}^{*}}{p^{0}}
$$

where $p_{I_{2}}^{*}$ is the saturated vapor pressure of the $I_{2}$ molecule, which can be calculated based on the Antonie equation (obtained from the NIST WebBook).

For good CE electrocatalysts, to ensure that the reaction occurs spontaneously, it is required that the chemical potentials conform to the sequence as follows:

$$
\mu_{I_{2}(\text { sol })}+2 \mu_{e} \geq 2 \mu_{I^{*}}+2 \mu_{e} \geq 2 \mu_{I^{-}(\text {sol })}
$$

By combining equations (14) and (18), we can obtain the theoretical deduction as follows:

$$
\begin{aligned}
& E_{I_{2}(\mathrm{gas})}-T \Delta S_{I_{2}}+\Delta \mu_{I_{2}}+2 E_{\text {sur }(\mathrm{sol})}+2 \mu_{e} \geq 2 E_{I^{*}} \\
& \quad+2 \mu_{e} \geq\left(\mu_{I_{2}(\mathrm{sol})}+2 \mu_{e}\right)-\Delta G_{0}
\end{aligned}
$$

where $T \Delta S_{I_{2}}$ is the entropy correction term of $I_{2}$ in a gas phase at $\mathrm{T}=298 \mathrm{~K}$ (relative to gaseous $I_{2}$ at $0 \mathrm{~K}$ ). Here, $\mu_{e}$ is the chemical potential of the electron, and $\mu_{I^{*}}$ can be defined as follows:

$$
\mu_{I^{*}}=\mu_{I^{*}}^{0}+R T \ln \frac{\theta_{I^{*}}}{\theta_{*}}
$$

where $\theta_{I^{*}}$ is the coverages of the absorbed $I^{\star}$; and $\theta_{*}$ is the free site ${ }^{*}$ on the CE's surface; and $\mu_{I^{*}}^{0}$ is the standard chemical potential of the $I^{\star}$ species, which can be readily obtained from the $E_{a d}^{I}$ using DFT calculations with the necessary thermal correction. For simplicity, the minor contribution of the $I_{2}$ and $I^{-}$concentrations in the solution ( $\sim 0.02 \mathrm{eV}$, estimated under experimental conditions) into the free energy was neglected. The coverage-dependent term $R T \ln \frac{\theta_{I^{*}}}{\theta_{*}}$, which was previously proposed by Cheng ${ }^{56}$, could occur within a small range for the best catalyst $(\sim 0.06-0.12 \mathrm{eV}$ at $298 \mathrm{~K})$ and was defined as $\varepsilon .{ }^{56}$

In other words, for a good electrocatalyst, $\mu_{I^{*}}$ should satisfy equation (21).

$$
\mu_{I^{*}}^{0}-\varepsilon \leq \mu_{I^{*}} \leq \mu_{I^{*}}^{0}+\varepsilon
$$

Here the suitable range of $E_{\text {ad }}^{\mathrm{I}}$ for a good CE electrocatalyst can be depicted as follows:

$$
\begin{aligned}
& 1 / 2 T \Delta S_{I_{2}}-1 / 2 \Delta \mu_{I_{2}}-\varepsilon \leq E_{a d}^{I} \leq 1 / 2 T \Delta S_{I_{2}}+1 / 2 \Delta G_{0} \\
& \quad-1 / 2 \mu_{I_{2}}+\varepsilon
\end{aligned}
$$

where $\Delta \mu_{I_{2}}$ is the chemical potential difference of the $I_{2}$ molecule between the gas phase and the $\mathrm{CH}_{3} \mathrm{CN}$ solvent at $298 \mathrm{~K}$.

Thus, there are upper and lower limits for $E_{a d}^{I}$ from equation (22): $E_{a d}^{I}$ is required to be high enough such that the $I_{2}$ dissociate adsorption is exothermic, and it needs to be low enough for the subsequent desorption to proceed exothermically (Figure 3a). Because the IRR is an electrode reaction, the electrode voltage effect needs to be considered (equation (16)). As illustrated in Figure 3b, the lower the electrode voltage $(\mathrm{U})$, the larger the absolute value of $\Delta G_{0}$. For the most common DSCs, which use $\mathrm{TiO}_{2}$ as the anode material, when the electrode voltage $U=U_{C B M}^{T \mathrm{iiO}}-U_{S H E} \approx-0.06 \mathrm{~V}$ (relative to SHE), ${ }^{57}$ $\Delta G_{0}$ reaches its maximum, which provides the maximal upper boundary for $E_{a d}^{I}$ according to equation (14). Therefore, under this condition, we estimated the variation range of $E_{a d}^{I}$ to be between 0.33 

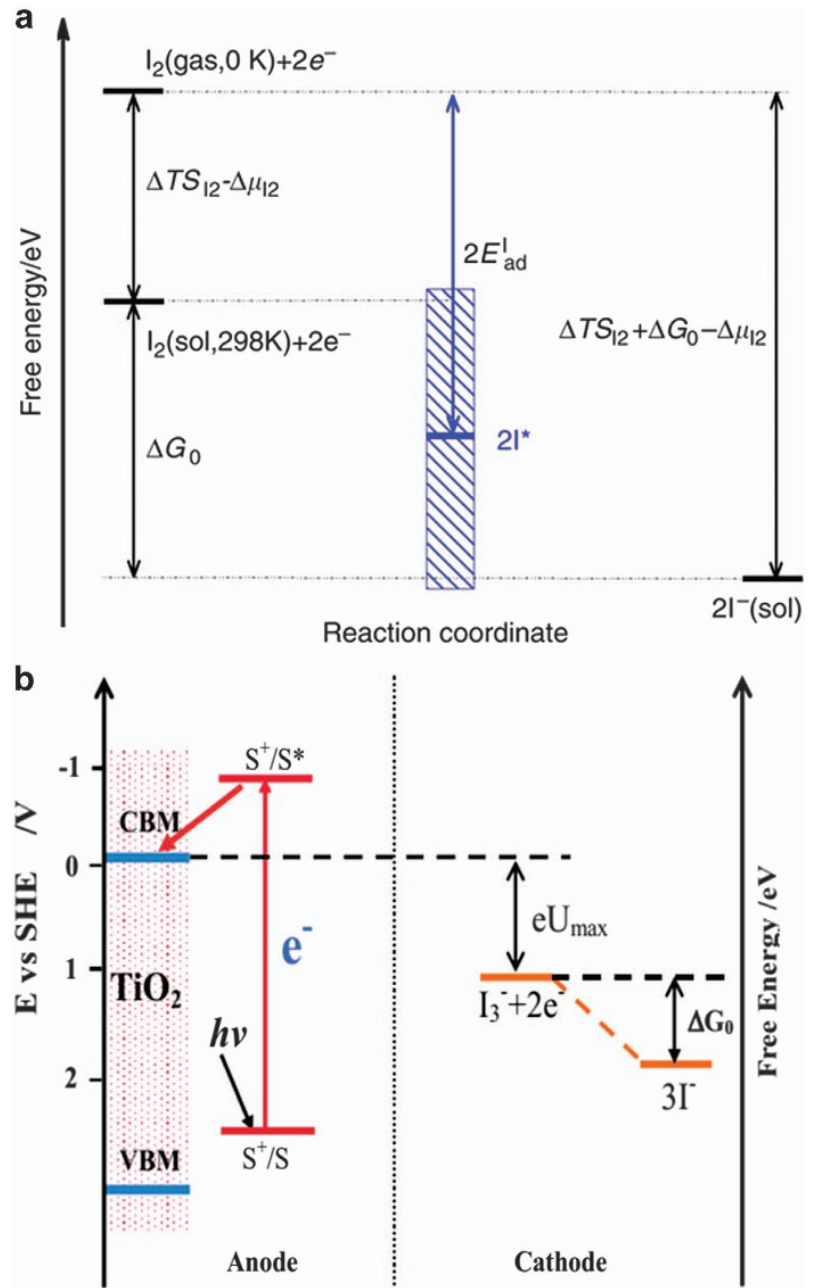

Figure 3 (a) Demonstration of the estimated range for suitable electrodes in terms of the adsorption energy of the I atom. Adapted from Hou et al. ${ }^{26}$ (b) Energy level scheme of the DSCs. Potentials are referred to the standard hydrogen electrode (SHE). Adapted from Zhang et al. ${ }^{58}$ Copyright (C) 2013 Rights Managed by Nature Publishing Group.

and $1.20 \mathrm{eV}$ for good CE electrocatalysts. It is worth noting that the first-principles simulations can handle system sizes of only $\sim 100$ atoms owing to the computational expense. Other factors that may also affect the performance of the CE electrocatalysts, such as nanoscale structures, electrical conductivity and macro/meso-scale morphologies, cannot be systematically considered using the DFT method. Therefore, the $E_{a d}^{I}$ can be used only as a qualitative predictor.

\section{APPLICATION OF SCREENING FRAMEWORK FOR EFFICIENT CE MATERIALS AND THEIR EXPERIMENTAL PERFORMANCES}

Once the optimal range of $E_{\text {ad }}^{\mathrm{I}}$ has been determined, it can be utilized as a guideline to estimate the electrocatalytic activity and, more importantly, search for new CE materials without the need to experimentally prepare the solar cells. It should be noted that the $E_{\mathrm{ad}}^{\mathrm{I}}$ value of one substance may vary as it depends on the exposed surface structures. Crystalline materials are first investigated because they are composed of atoms with highly ordered microscopic arrangements; therefore, they are easier to prepare, model and are more stable in the long term.

Essentially, the DFT is used to create a stabilized crystal surface model of the CE candidates and calculate the $E_{\text {ad }}^{\mathrm{I}}$ values of the relevant

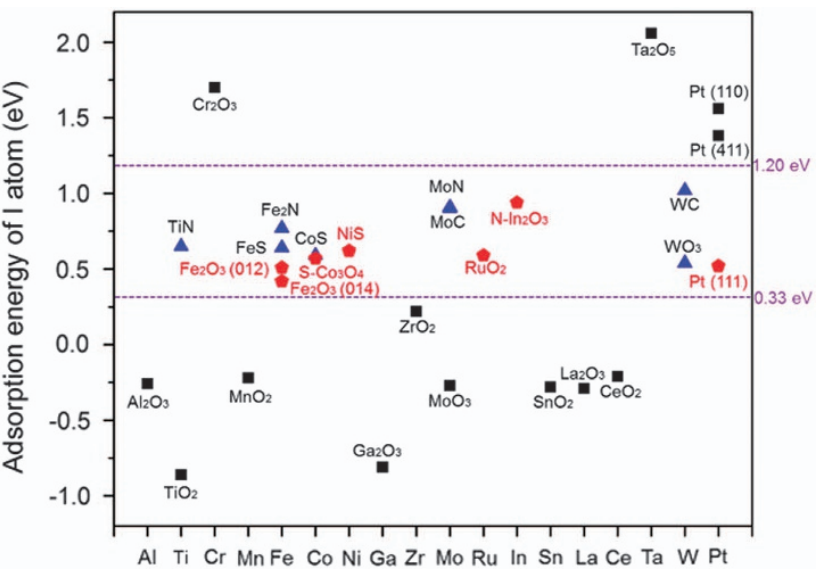

Figure 4 Calculation of the adsorption energy of the I atom for various compounds and estimation of the optimal range of $E_{\text {ad }}^{l}$.

surfaces. Using the established CE material screening strategy, a range of different materials, including metals, metal oxides, metal carbides, metal nitrides and metal sulfides, have been examined by our group, as summarized in Figure 4. A few materials have been previously experimentally proven to be good $\mathrm{CE}$ electrocatalysts, (blue triangles in Figure 4), such as $\mathrm{CoS}, \mathrm{FeS}, \mathrm{MoC}, \mathrm{MoN}, \mathrm{WC}$ and $\mathrm{WO}_{3}$, which possess favorable $E_{\text {ad }}^{\mathrm{I}}$ values. The theory-experiment match confirms the feasibility of this strategy. On the other hand, the $E_{\text {ad }}^{\mathrm{I}}$ values of the metal oxides, including $\mathrm{TiO}_{2}, \mathrm{MnO}_{2}, \mathrm{SnO}_{2}, \mathrm{CeO}_{2}, \mathrm{ZrO}_{2}, \mathrm{La}_{2} \mathrm{O}_{3}$, $\mathrm{Al}_{2} \mathrm{O}_{3}, \mathrm{Ga}_{2} \mathrm{O}_{3}, \mathrm{Cr}_{2} \mathrm{O}_{3}$ and $\mathrm{Ta}_{2} \mathrm{O}_{5}$, are out of the optimal range (black squares in Figure 4), which indicates inferior catalytic activities. Using this screening strategy, we successfully predicted the pioneer facet of $\mathrm{Pt}$ (111) of the triiodide reduction reaction. ${ }^{58}$ Several excellent Pt-free CE materials (red pentagon in Figure 4), including $\alpha-\mathrm{Fe}_{2} \mathrm{O}_{3},{ }^{26} \mathrm{RuO}_{2},{ }^{59}$ $\mathrm{N}$-doped $\mathrm{In}_{2} \mathrm{O}_{3}\left(\mathrm{~N}-\mathrm{In}_{2} \mathrm{O}_{3}\right),{ }^{60}$ S-doped $\mathrm{Co}_{3} \mathrm{O}_{4}\left(\mathrm{~S}-\mathrm{Co}_{3} \mathrm{O}_{4}\right)^{61}$ and NiS, ${ }^{62}$ also have an $E_{\text {ad }}^{\mathrm{I}}$ value within the optimal range. The calculated results are subsequently proven by experimental measurement of the $\mathrm{CE}$ materials, as discussed below.

\section{Metals}

As a noble metal, Pt has been recognized as the best classic material that can be used for various heterogeneous catalytic reactions, such as the triiodide reduction reaction, ${ }^{58}$ oxygen reduction reaction, ${ }^{63}$ hydrogen evolution reaction ${ }^{64}$ and so on. Platinum is known to be a unique catalytic material because of its exceptional stability in corrosive electrolytes, good electrical and thermal conductivity and excellent electrocatalytic activity. ${ }^{65}$ Specifically, Pt has been the benchmark CE material used in the DSCs owing to its unparalleled catalytic performance in the $I^{-} / I_{3}^{-}$redox mediator system. In addition, the diverse catalytic activities of the Pt nanocrystals are known to be highly dependent on the exposed facets of the Pt surface. ${ }^{66}$ To investigate the facet-dependent catalytic behavior of the different faceted Pt nanocrystal, we calculated the $E_{\text {ad }}^{\mathrm{I}}$ values for three different facets $(\{100\}$, $\{111\}$ and $\{411\})$, and the facet with the best catalytic activity for the IRR was discovered. ${ }^{58}$ Upon adsorption at the interfaces of these Pt surfaces and the $\mathrm{CH}_{3} \mathrm{CN}$ solution, the $I_{2}$ molecule was found to dissociate into two $I^{\star}$ atoms without an apparent $E_{\mathrm{a}}^{\mathrm{dis}}$, which suggests that the dissociation of $I_{2}$ is quite fast and can be considered to be in equilibrium. Therefore, the IRR process is determined by the desorption step. As indicated in Figure $5 \mathrm{a}-\mathrm{c}$, the elongated distance between the Pt and the I atom was observed for the $\mathrm{Pt}(100)$ and $\operatorname{Pt}(411)$ surfaces (4.48 and $4.49 \AA$, respectively) to be greater than that 

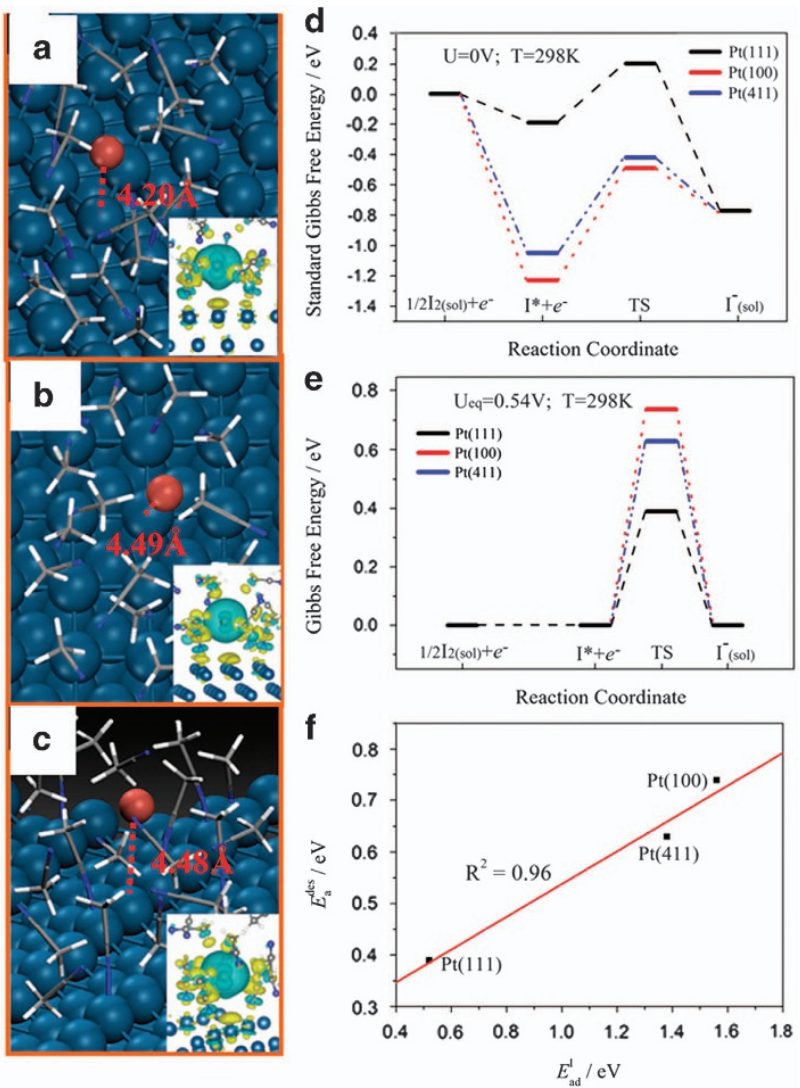

Figure 5 Transition-state (TS) structures at (a) $\mathrm{CH}_{3} \mathrm{CN} / \mathrm{Pt}\left(111\right.$ ), (b) $\mathrm{CH}_{3} \mathrm{CN}$ $\mathrm{Pt}(100)$ and (c) $\mathrm{CH}_{3} \mathrm{CN} / \mathrm{Pt}(411)$ interfaces; inserts: corresponding chargedensity-difference map of TS, and a light-blue color represents electron accumulation and yellow represents electron depletion. (d) Standard Gibbs free-energy profiles of the IRR on Pt(111), Pt(100), Pt(411). (e) Gibbs free-energy profiles of the IRR on Pt(111), Pt(100), Pt(411), under the $I^{-} / I_{3}^{-}$equilibrium voltage of $0.54 \mathrm{~V}$. (f) Linear relationship between the $1^{*}$ desorption barrier $\left(E_{\mathrm{a}}^{\mathrm{des}}\right)$ and the adsorption energy $\left(E_{\mathrm{ad}}^{1}\right)$. Adapted from Zhang et al. ${ }^{58}$ Copyright (C) 2013 Rights Managed by Nature Publishing Group.

of the $\operatorname{Pt}(111)$ counterpart (4.20 $\AA)$. The charge-density-difference between the $I$ and $\mathrm{Pt}$ atoms in their transition states are displayed in Figure $5 \mathrm{a}-\mathrm{c}$ (inset) to depict the bond properties. On the investigated $\mathrm{Pt}$ surfaces, the electrons that were depleted at the surface of the $\mathrm{Pt}$ atom and the adsorbed $\mathrm{CH}_{3} \mathrm{CN}$ molecules were found to accumulate at the adsorbed I atoms. The reaction energy profile of the IRR on these three Pt surfaces is illustrated in Figure $5 \mathrm{~d}$ and e. To remove the effects of the electrode voltage on the electron potential, the electrode voltage was set as $\mathrm{U}=0 \mathrm{~V}$ vs $\mathrm{SHE}$, which provides the largest thermodynamic driving force (Figure $5 \mathrm{~d}$ ). The corresponding $E_{\mathrm{a}}^{\text {des }}$ values for the $\mathrm{Pt}(111), \mathrm{Pt}(100)$, and $\mathrm{Pt}(411)$ surfaces were calculated to be $0.39,0.63$ and $0.74 \mathrm{eV}$, respectively. This result indicates that the desorption of the I atoms from the $\mathrm{Pt}(100)$ or $\mathrm{Pt}(411)$ surfaces becomes more difficult than that of the $\mathrm{Pt}(111)$ surface. Furthermore, under the equilibrium voltage $(0.54 \mathrm{~V})$, the free-energy change of the IRR reaches zero (Figure 5e). On the basis of the DFT calculation, $\mathrm{Pt}(111)$ possesses a favorable $E_{\text {ad }}^{\mathrm{I}}$ of $0.52 \mathrm{eV}$. However, on $\mathrm{Pt}(411)$ and $\operatorname{Pt}(100)$, the $E_{\text {ad }}^{\mathrm{I}}$ values are beyond the optimal range, that is, 1.38 and $1.56 \mathrm{eV}$, respectively, which indicates less electrocatalytic activity.

To experimentally validate the theoretical prediction, Pt nanocubes and truncated nano-octahedrons with exposed $\{100\}$ and $\{111\}$ facets
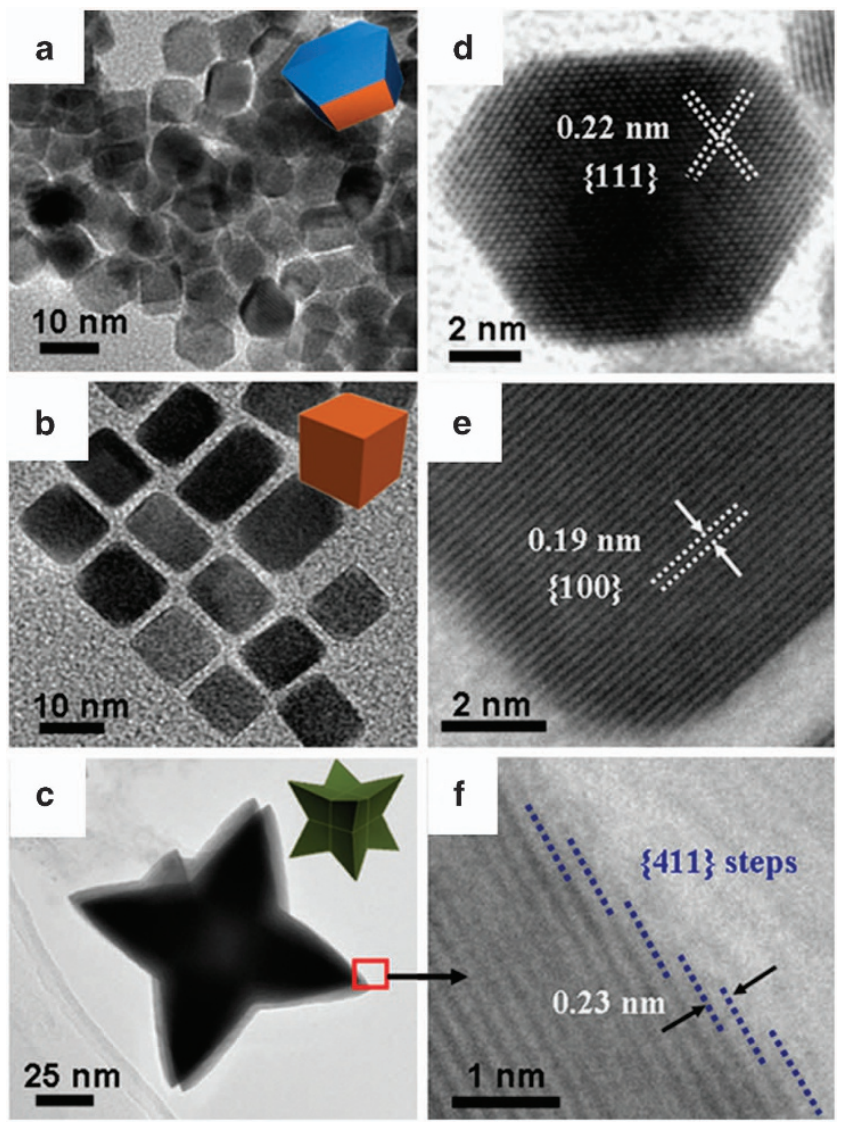

Figure 6 Morphologies and crystal structure of (a, d) Pt(111), (b, e) Pt(100) and $(\mathbf{c}, \mathbf{f}) \mathrm{Pt}(411)$ faceted Pt nanocrystals. Adapted from Zhang et al. ${ }^{58}$ Copyright @ 2013 Rights Managed by Nature Publishing Group.

were synthesized by a soft chemical method using $\mathrm{CO}$ derived from $\mathrm{W}(\mathrm{CO})_{6}$ as a reducing agent under an argon atmosphere, whereas $\mathrm{Pt}$ nanooctapods with exposed $\{411\}$ facet was prepared using a solvothermal method at $160^{\circ} \mathrm{C}$, as indicated in Figure $6 .^{67,68}$ These individual Pt nanocrystals were used as the CE materials in the DSCs, and $\operatorname{Pt}(111)$ was found to be the prominent facet for the triiodide reduction reaction, which is consistent with the theoretical prediction. The maximum PCE was found to be $6.91 \%$, with a high current density $\left(J_{\mathrm{sc}}=16.29 \mathrm{~mA} \mathrm{~cm}^{-2}\right)$ and a large open circuit voltage $\left(V_{o c}\right)$ of $757 \mathrm{mV}$. The DSCs with the $\mathrm{Pt}(100)$ and $\mathrm{Pt}(411)$ faceted Pt CE exhibited relatively lower PV performances than that of the $\mathrm{Pt}(111)$ faceted Pt CE, and the overall PCE order was $\mathrm{Pt}(111)>\mathrm{Pt}(411)>\mathrm{Pt}$ (100), which is consistent with the theoretical prediction. ${ }^{58}$ In addition to the facets, the structural morphology was also reported to significantly influence the catalytic behavior by exposing the excessive catalytic sites for effective electrocatalysis. ${ }^{69-73}$ In addition to $\mathrm{Pt}$, a few other metals, such as $\mathrm{W}, \mathrm{Mo}$ and $\mathrm{Ni}$, have also been tested as a $\mathrm{CE}$ material in the DSCs; however, the PCEs were significantly lower than that of the Pt CE. ${ }^{15,74}$

\section{Metal oxides}

Semiconducting transition metal oxides that possess a reasonable band gap for photoexcitation are thought to be potential candidates as photoanode materials instead of CE materials in DSCs. ${ }^{75-77}$ Among all of the semiconducting metal oxides, $\alpha-\mathrm{Fe}_{2} \mathrm{O}_{3}$ is one of the most abundant and low-cost materials on earth. On the basis of the theoretical calculations, the $E_{\text {ad }}^{\mathrm{I}}$ values of the two typical surfaces of 
$\alpha-\mathrm{Fe}_{2} \mathrm{O}_{3}$ (that is, $\mathrm{Fe}_{2} \mathrm{O}_{3}(012)$ and $\mathrm{Fe}_{2} \mathrm{O}_{3}(104)$ ) were estimated to be 0.51 and $0.42 \mathrm{eV}$, respectively, indicating that it may be catalytically active. $^{26}$ To further investigate the activity of $\alpha-\mathrm{Fe}_{2} \mathrm{O}_{3}$, the reaction pathway of the IRR at the interface between $\mathrm{CH}_{3} \mathrm{CN} / \mathrm{Fe}_{2} \mathrm{O}_{3}(012)$ and $\mathrm{CH}_{3} \mathrm{CN} / \mathrm{Fe}_{2} \mathrm{O}_{3}(104)$ was calculated using the DFT. ${ }^{26}$ The $I_{2}$ molecules can dissociate directly on top of the five-coordinated surface $\mathrm{Fe}^{3+}$ ions. Compared with the initial Fe-I bond length $(2.72 \AA)$ in the adsorption configuration, the transition state of the $I^{\star}$ desorption exhibited a significantly elongated Fe-I bond length (4.12 $\AA$ ) (Figure 7a-c). No particular high point was found in the overall standard free-energy profiles (Figure 7d) for both the $\mathrm{Fe}_{2} \mathrm{O}_{3}(012)$ and $\mathrm{Fe}_{2} \mathrm{O}_{3}$ (104) surfaces, implying a good kinetic performance for the IRR compared with the $\mathrm{Pt}(111)$. To verify the expected catalytic activity of $\alpha-\mathrm{Fe}_{2} \mathrm{O}_{3}$, a simple hydrothermal method was used to prepare cube-like $\alpha-\mathrm{Fe}_{2} \mathrm{O}_{3}$ nanoparticles that have generally exposed $\{012\}$ and $\{104\}$ facets and used as a CE in the DSCs to evaluate the PV parameters. The experimental results (Figure 8) indicate that the $\alpha-\mathrm{Fe}_{2} \mathrm{O}_{3}$-based DSC can record a $J_{\mathrm{sc}}$ of $15.92 \mathrm{~mA} \mathrm{~cm}^{-2}$, a $V_{\mathrm{oc}}$ of $784 \mathrm{mV}$, a fill factor of 0.56 and a PCE of $6.92 \%$, which is comparable with that of the Pt-based DSC (Figure 8b and c). Furthermore, from the electrochemical impedance spectroscopic data, $\alpha-\mathrm{Fe}_{2} \mathrm{O}_{3}$ has a lower interfacial charge transfer resistance $\left(R_{c t}\right)$ value $(2.3 \Omega)$ than that of $\operatorname{Pt}(3.4 \Omega)$, which further confirmed the excellent catalytic activity for the triiodide reduction reaction. Another transition metal oxide, $\mathrm{RuO}_{2}$, possesses superior electrocatalytic activity in different heterogeneous catalysis, such as oxidation reactions, reduction/hydrogenation reactions, oxygen evolution reactions ${ }^{78}$ and ammonia synthesis. ${ }^{79}$ Regarding the IRR, the DFT calculation was used to estimate the $E_{\text {ad }}^{\mathrm{I}}$ value at the $\mathrm{CH}_{3} \mathrm{CN} / \mathrm{RuO}_{2}$ interface. The
$\mathrm{RuO}_{2}(110)$ surface contained exposed rows of five-coordinated $\mathrm{Ru}$ cations $\left(\mathrm{Ru}_{5 \mathrm{c}}\right)$, which constituted typical catalytically active sites. Upon adsorption on the $\mathrm{Ru}_{5 \mathrm{c}}$ row, the $I_{2}$ readily dissociated into two $I^{*}$ without any apparent dissociation barrier. The $E_{\text {ad }}^{\mathrm{I}}$ was calculated to be $0.59 \mathrm{eV}$, which was similar to that of the $\operatorname{Pt}(111)$ surface $(0.52 \mathrm{eV})$ and within the optimal range. ${ }^{59}$ Therefore, $\mathrm{RuO}_{2}$ is expected to be a catalytically active CE electrocatalyst for the triiodide reduction reaction. In the past, Papageorgiou et al. ${ }^{80}$, reported the promising $R_{c t}$ of $\mathrm{RuO}_{2}$ and our recent theoretical study also support the previous findings. ${ }^{59}$ Interestingly, the $\mathrm{RuO}_{2}$ nanocrystals were found to afford almost same level of catalytic performance (7.22\%) compared with $\mathrm{Pt}$ (7.17\%). The extraordinary catalytic behavior of $\mathrm{RuO}_{2}$ might be owing to the favorable adsorption-desorption energy and good electrical conductivity within the nanocrystals..$^{59}$

As another useful metal oxide, $\mathrm{WO}_{3}$ has been firstly utilized as $\mathrm{CE}$ material in DSCs and the overall PCE was reported to be $4.67 \% .{ }^{81}$ Our theoretical prediction suggested that $\mathrm{WO}_{3}$ could be an efficient electrocatalyst for triiodide reduction reaction as its $E_{\text {ad }}^{\mathrm{I}}(0.54 \mathrm{eV})$ is very close to that of standard Pt. The inferior PCE of commercial $\mathrm{WO}_{3}$-based DSC was found in our group, however, after hydrogen treatment $\left(\mathrm{H}-\mathrm{WO}_{3}\right)$, the overall PCE markedly improved and reached $5.43 \%$. The origin of the catalytic activity of the $\mathrm{H}-\mathrm{WO}_{3}$ may result from the oxygen vacancy created by the hydrogen treatment, which eased the facile adsorption of the $I_{3}^{-}$species on the vacant sites and thereby enhanced the electrocatalytic performance. ${ }^{82}$ Meanwhile, other tungsten oxides, such as $\mathrm{WO}_{2}$ and $\mathrm{W}_{18} \mathrm{O}_{49}$, also showed exceptional catalytic ability toward the triiodide reduction, leading to PCEs of 7.25 and $7.94 \%$, respectively, which were extremely close to that of the
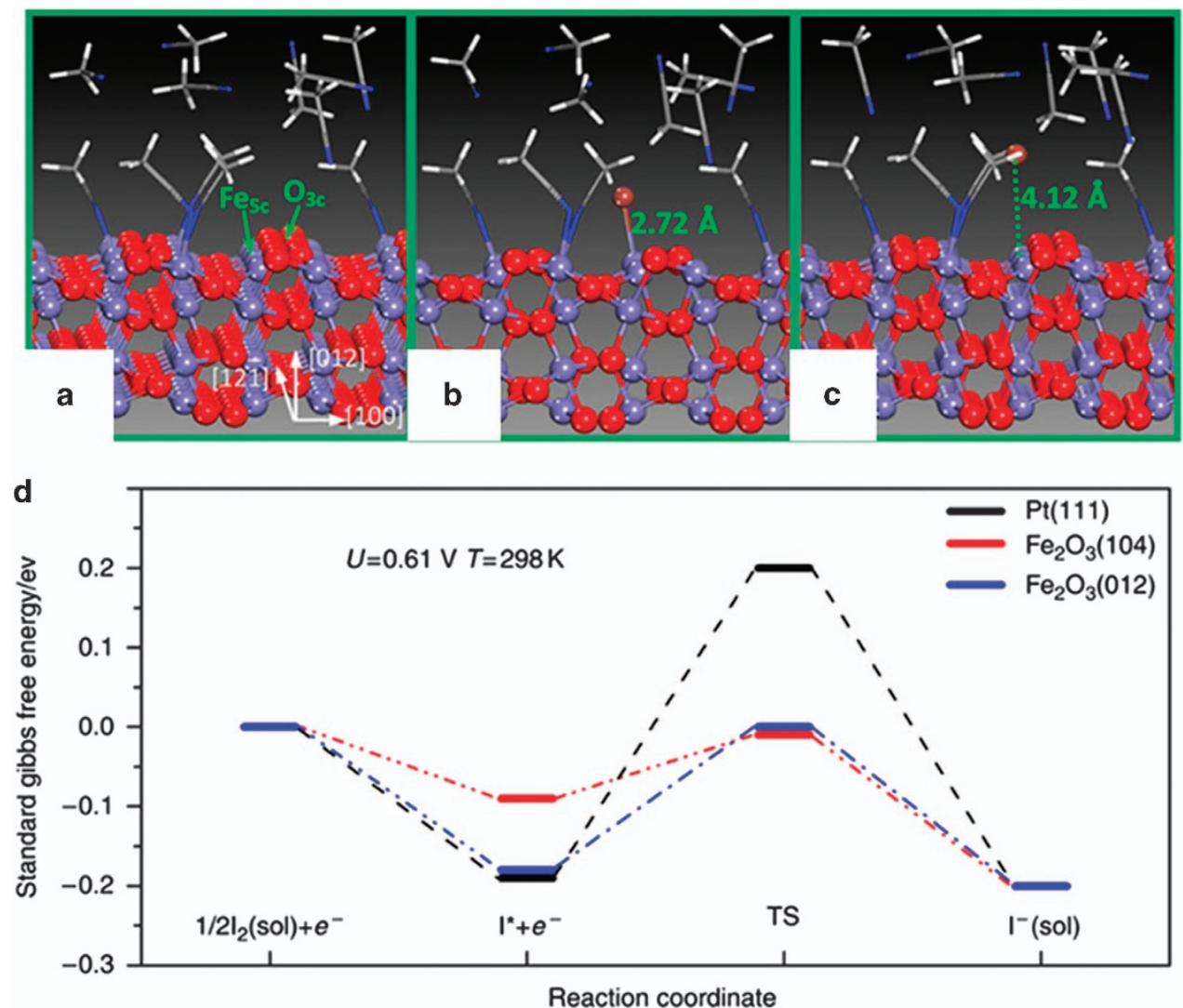

Figure 7 (a-c) $\alpha-\mathrm{Fe}_{2} \mathrm{O}_{3}$ surface structure in the presence of the $\mathrm{CH}_{3} \mathrm{CN}$ solvent, I adsorption structure and transition-state structure. (d) Energy profiles of the CE reaction on $\mathrm{Pt}(111), \mathrm{Fe}_{2} \mathrm{O}_{3}(104)$ and $\mathrm{Fe}_{2} \mathrm{O}_{3}(012)$, which were calculated at $U=0.61 \mathrm{~V}$ vs SHE. Adapted from Hou et al. ${ }^{26}$ Copyright $(0) 2013 \mathrm{Rights}$ Managed by Nature Publishing Group. 

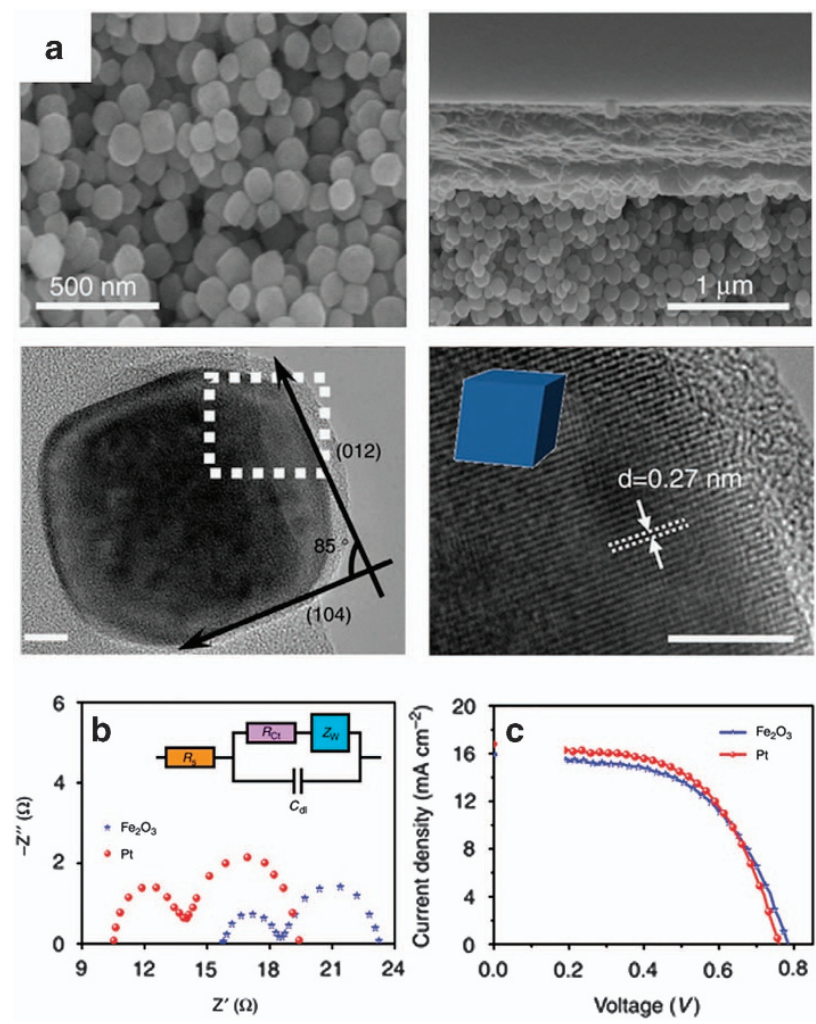

Figure 8 (a) Surface morphology, cross-sectional view and TEM images of the $\alpha-\mathrm{Fe}_{2} \mathrm{O}_{3}$ nanoparticle film. (b) Nyquist plots for the symmetrical cells of the $\alpha-\mathrm{Fe}_{2} \mathrm{O}_{3}$ and Pt electrodes. (c) $\mathrm{J}-\mathrm{V}$ characteristic curves for $\alpha-\mathrm{Fe}_{2} \mathrm{O}_{3}$ and the Pt-based DSCs. Adapted from Hou et al. ${ }^{26}$ Copyright (C) 2013 Rights Managed by Nature Publishing Group.

standard $\mathrm{Pt}^{81,83}$ The authors believe that the underlying reason for the exceptional catalytic activity of $\mathrm{W}_{18} \mathrm{O}_{49}$ is the oxygen vacancies of $\mathrm{W}_{18} \mathrm{O}_{49}$, which can offer abundant active sites for the triiodide reduction reaction. Furthermore, the charge transport can be facilitated with the one-dimensional nanofiber structure. Moreover, our rational screening strategy anticipated a few other metal oxides, such as $\mathrm{TiO}_{2}, \mathrm{MnO}_{2}, \mathrm{SnO}_{2}, \mathrm{CeO}_{2}, \mathrm{MoO}_{3}, \mathrm{Al}_{2} \mathrm{O}_{3}, \mathrm{Ga}_{2} \mathrm{O}_{3}, \mathrm{La}_{2} \mathrm{O}_{3}, \mathrm{Cr}_{2} \mathrm{O}_{3}$, $\mathrm{Ta}_{2} \mathrm{O}_{5}$ and $\mathrm{ZrO}_{2}$, which may possess limited activity toward the triiodide reduction reaction because of their low-adsorption energy. A few of these oxides, such as $\mathrm{TiO}_{2}, \mathrm{Cr}_{2} \mathrm{O}_{3}$ and $\mathrm{ZrO}_{2}$, were tested as CE electrocatalysts in the DSCs, and their PCEs values were found to be $0.76,1.07$ and $2.60 \%$, respectively, as reported by $\mathrm{Wu}$ et al. ${ }^{18}$ (Figure 9), which further validated the screening framework. Yun et al. ${ }^{84}$ investigated the $\mathrm{HfO}_{2}$ as a catalytic CE material in the DSCs, and their result indicated that its catalytic performance $(7.75 \%)$ was superior to that of standard $\mathrm{Pt}(7.20 \%)$ when $\mathrm{HfO}_{2}$ was supported by mesoporous-graphitic-carbon. A recent study also suggested that spinel types of ternary oxides, such as $\mathrm{CoCr}_{2} \mathrm{O}_{4}$, can also be used as the CE material in the DSCs, and the overall PCE was reported to be $8.40 \%$, which is close to that of the Pt-based DSCs $(8.68 \%) .{ }^{85}$

\section{Metal sulfides}

Transition metal sulfides are one of the most promising classes of CE electrocatalysts used to replace Pt owing to their outstanding electrocatalytic activity, thermal and chemical stability, abundant feedstock and low cost. ${ }^{9}$ On the basis of theoretical calculations, the $E_{\text {ad }}^{\mathrm{I}}$ value for the most abundant facets of the CoS was estimated to be $0.59 \mathrm{eV}$, which lies within the range of $0.33-1.20 \mathrm{eV}$. Among all of the cobalt

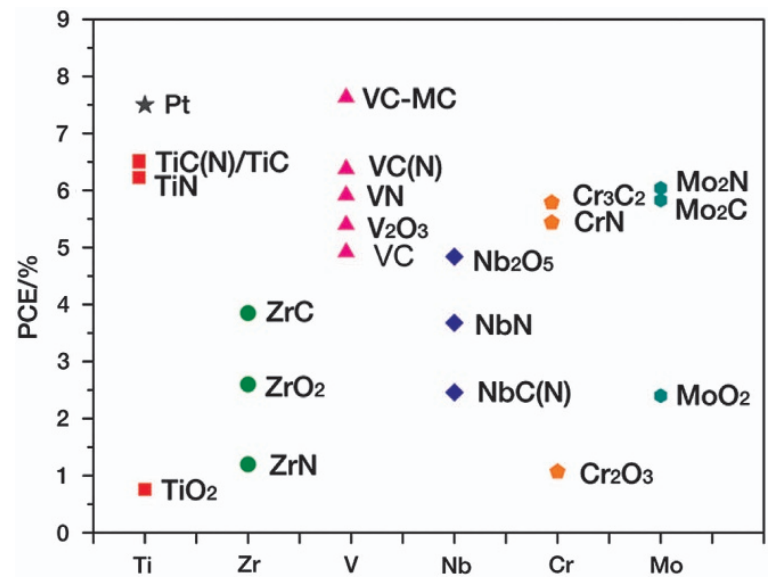

Figure 9 Photovoltaic performances and distribution of the relative PCE of late transition metal carbides, nitrides and oxides as CE catalysts in the $I^{-} / I_{3}^{-}$electrolyte system. Adapted from Wu et al. ${ }^{18}$ Copyright (C) 2012 American Chemical Society.

sulfides, $\mathrm{CoS}$ has been proven to be an efficient CE material in the DSCs. The first study was performed by Wang et al. ${ }^{16}$, who electrochemically deposited $\operatorname{CoS}$ nanoparticles on a flexible ITO/PEN substrate and applied it as a CE in the DSCs with a promising PCE of $6.5 \%$. Later, this $\mathrm{CoS}$ material was further explored by several scientists, and the surface morphology and the electrical conductivity of the $\mathrm{CoS}$ films were found to be critically important for electrocatalysis in the triiodide reduction reaction, as reported by Lin et al. ${ }^{86} \mathrm{~A}$ controlled potentiodynamic deposition of $\mathrm{CoS}$ can produce a highly porous CoS film with an extremely low $R_{c t}$ value $\left(\sim 1.03 \Omega \mathrm{cm}^{2}\right)$ and be used as an electrocatalyst $(6.33 \%)$ that is superior to Pt $(6.06 \%)$. Kung et al. ${ }^{87}$ prepared one-dimensional CoS acicular nanorod arrays (ANRAs) by converting $\mathrm{Co}_{3} \mathrm{O}_{4}$ ANRAs into $\mathrm{CoS}$ ANRAs without damaging the structural integrity using a simple chemical-bath process at a relatively low temperature of $90^{\circ} \mathrm{C}$ for $24 \mathrm{~h}$ (Figure 10a and b). The CoS ANRAs CE displayed a larger catholic current density than that of Pt (Figure 10c), with an exceptional catalytic stability toward the triiodide reduction reaction after 200 cycles of consecutive runs (Figure 10d) and the PCE was reported to be as high as $7.67 \%$, which is close to the standard Pt-based DSCs $(7.70 \%)$. Another study was performed by $\mathrm{Hsu}$ et al. ${ }^{88}$, who synthesized the $\mathrm{CoS}$ nanoparticles with controlled particle sizes ranging from 50 to $320 \mathrm{~nm}$ using a surfactant-assisted preparation of a metal organic framework along with subsequent oxidation and sulfidation processes. Then, different composites of CoS with graphene, ${ }^{89}$ multi-wall carbon nanotubes (MWCNT) ${ }^{90}$ and PEDOT: PSS $^{91}$ were identified as potential CE candidates, especially CoS nanocomposite with MWCNT outperformed the Pt-based DSC $(6.39 \%)$, and the PCE was as high as $8.05 \% . .^{90}$

Similarly, NiS has been of particular interest owing to its salient electrocatalytic activity, earth abundance and cost effectiveness. ${ }^{62}$ In our study, we determined that a $\{0001\}$-faceted single-crystal NiS nanosheet film, as shown in Figure 11a and b, can be used as a superior $\mathrm{CE}$ for the triiodide reduction reaction owing to its exceptional crystal structure and sulfur vacancy-induced catalysis. ${ }^{62}$ The presence of the sulfur vacancy was found to be responsible for the rapid dissociation of $I_{2}$ into two $I^{\star}$ atoms, which has a stretched bond length of $3.664 \AA$ compared with the free $I_{2}$ molecular bond length of $2.681 \AA$ (Figure $11 \mathrm{c}$ and $\mathrm{d}$ ), indicating sufficient activation power of the NiS(0001) surface toward the $I_{2}$ molecule. Along with the unique 

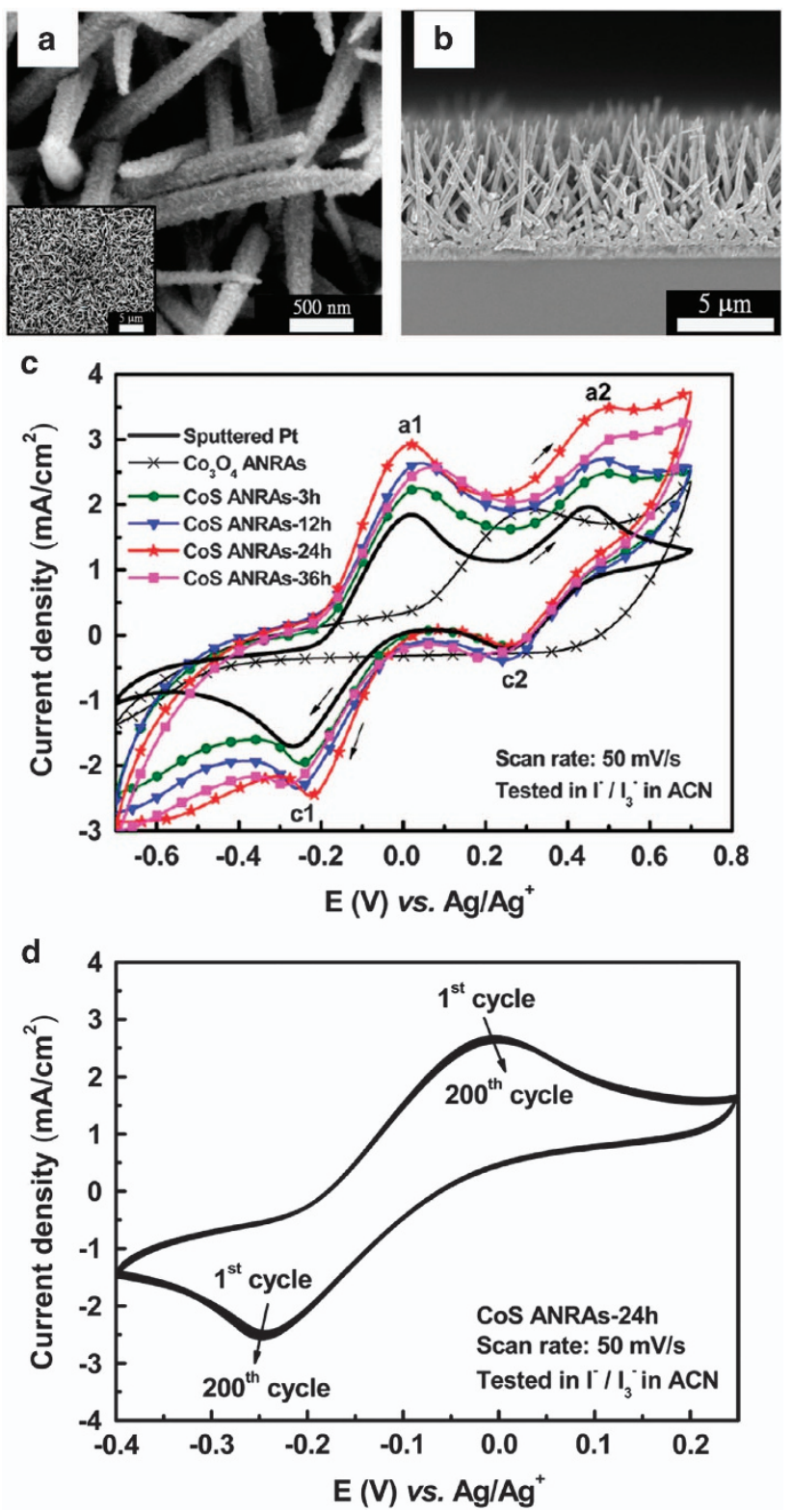

Figure 10 (a) SEM images for surface morphology. (b) Cross-section of the $\mathrm{CoS}$ acicular nanorod arrays (ANRAs) prepared at a $24 \mathrm{~h}$ reaction time. The inset of a depicts a large-scale SEM image of the corresponding ANRAs. (c) Cyclic voltammetry (CV) curves. (d) Stability test of the ANRAs in the $I^{-} / I_{3}^{-}$electrolyte. Adapted from Kung et al. ${ }^{87}$ Copyright (C) 2012 American Chemical Society.

adsorption sites, the descriptor $\left(E_{\mathrm{ad}}^{\mathrm{I}}\right)$ value was calculated to be $0.62 \mathrm{eV}$, which is within the optimal range of efficiently good electrocatalysts and close to that of the $\mathrm{Pt}(111)$ surface. An outstanding PCE of $8.62 \%$ was achieved with the DSCs equipped with $\{0001\}$ faceted NiS CE, which is $17.1 \%$ higher than that of the PCE obtained from the Pt-based DSCs (7.36\%). In addition, an interesting 'two-inone' CE-based on a single crystalline NiS grown on bare glass using a simple one-pot hydrothermal approach was realized by Zhao et al. ${ }^{92}$ In their report, they tested oriented NiS nanorod arrays that could be used to replace transparent conductive oxide and Pt. The device made of Pt and transparent conductive oxide-free CE displayed a PCE of $7.41 \%$, which was close to the PCE obtained from the DSC prepared with the transparent conductive oxide-supported Pt CE (7.55\%).
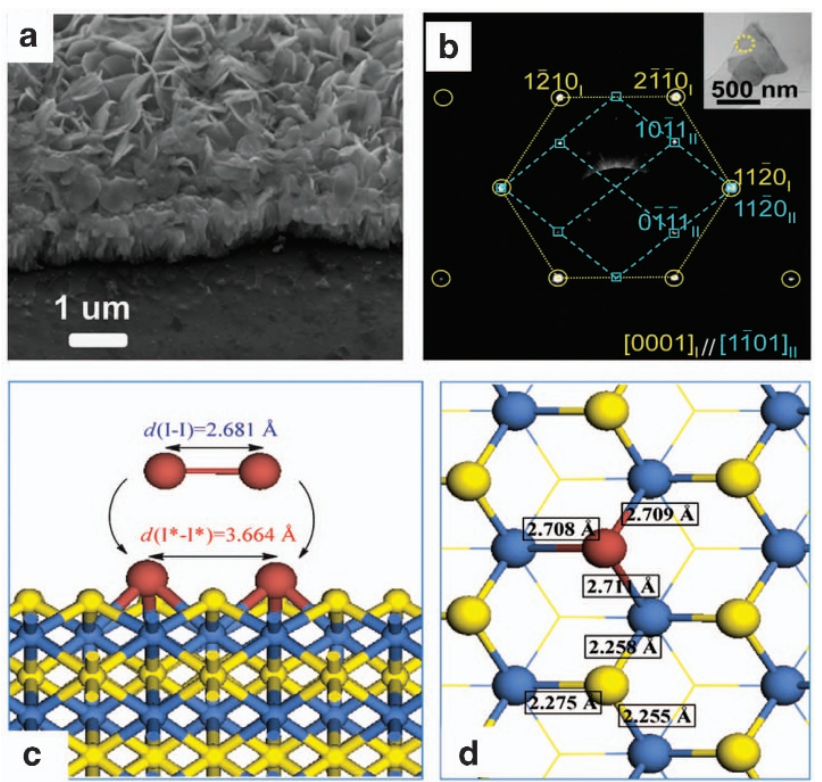

Figure 11 (a) Cross-sectional SEM image. (b) SAED pattern of hydrothermally synthesized $\{0001\}$-faceted NiS nanosheet film. The inset of b depicts the TEM image of the NiS nanosheet film. (c) Direct dissociation of the $I_{2}$ molecule upon adsorption at the S-vacancy dimer in the direction of $(0001)$ at the NiS(0001) surface. (d) Adsorption configuration of the I atom sitting at the S-vacancy position. Light-blue, yellow and brown represent the $\mathrm{Ni}, \mathrm{S}$ and I atoms, respectively. Adapted from $\mathrm{Li}$ et al.62 Copyright (C) 2014 Royal Society of Chemistry.

Xiao et al..$^{93}$ investigated an NiS composite with MWCNTs as the CE material in the DSCs. Initially, the MWCNTs were electrophoretically deposited on a Ti foil, and a nano-corallines NiS was deposited over it using a potentiostatic method; this hybrid system was able to produce an enhanced PCE of up to $7.90 \%$, which was higher than that of the PCE obtained from the DSC prepared with the Pt/Ti CE (6.36\%). Furthermore, the NiS/graphene composite CE-based DSCs indicated a larger PCE value (5.25\%) than that of the Pt-based one $(5.00 \%){ }^{89}$

Another metal sulfide, FeS, was predicted to be potentially active for the triiodide reduction reaction because of its calculated $E_{\text {ad }}^{\mathrm{I}}$ value of $0.64 \mathrm{eV}$, which is similar to that of Pt $(0.52 \mathrm{eV})$. Unfortunately, this material has not been widely studied in the past because of its pyrophoric and non-stoichiometric nature. Hu et al. ${ }^{94}$ synthesized an FeS nanosheet film on an iron foil using a simple hydrothermal treatment in the presence of sulfur powder. The resulting film was fitted as a CE in tandem-type DSCs using $I^{-} / I_{3}^{-}$as a redox couple, and a PCE of $1.32 \%$ was obtained.

$\mathrm{MoS}_{2}$ with a layer structure has attracted considerable attention as a CE material because of its analogous structure to that of graphene and potential electrocatalytic activity ${ }^{95}$ However, no theoretical calculation of $\mathrm{MoS}_{2}$ as a CE material has been available thus far. The application of $\mathrm{MoS}_{2}$ and $\mathrm{WS}_{2}$ as efficient electrocatalysts in the DSCs was first published by Wu et al. ${ }^{96}$ in 2011, and the obtained PCEs were 7.59 and $7.73 \%$, respectively, which is comparable with the Pt CE. In our study, we directly grew a semi-transparent ultrathin $\mathrm{MoS}_{2}$ nanostructured film on an FTO substrate using a hydrazine-assisted hydrothermal method and used it as a CE in the DSCs. ${ }^{97}$ The obtained $\mathrm{MoS}_{2}$ film as a CE for the DSC can afford a PCE up to $7.41 \%$, which was slightly better than that of the Pt-based DSC $(7.13 \%)$. Further studies on both of the sulfides were performed, and an outstanding PCE (outperforming Pt) was achieved with the 

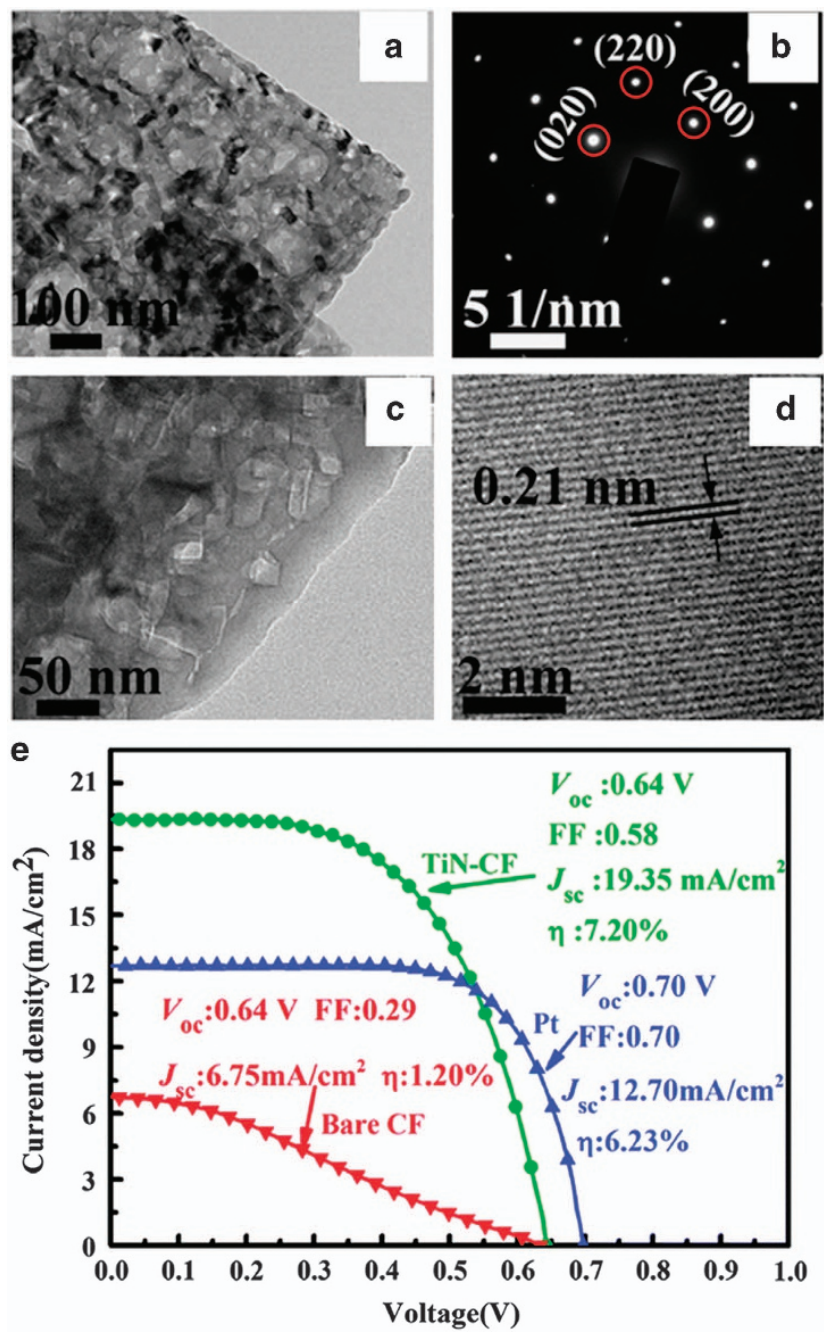

Figure 12 (a, c) TEM images, (b) SAED, (d) HRTEM images for the TiN nameplates. (e) $J-V$ characteristic curves of the DSCs prepared using TiN-CF, Pt wire and bare CF as the CE. Adapted from Chen et al. ${ }^{113}$ Copyright (C) 2014 Royal Society of Chemistry.

introduction of carbon. ${ }^{24}$ Thus far, different sulfides of metals, such as cobalt, ${ }^{98}$ nickel ${ }^{99}$ bismuth, ${ }^{100}$ tin, ${ }^{101}$ antimony, ${ }^{102}$ iron, ${ }^{103}$ tungsten ${ }^{104}$ and titanium ${ }^{105}$ have been studied as CE electrocatalysts in the DSCs. In addition to binary sulfides, a few tertiary or quaternary sulfides, including $\mathrm{CuInS}_{2},{ }^{106} \mathrm{NiCo}_{2} \mathrm{~S}_{4},{ }^{107} \mathrm{CoMoS}_{4}, \mathrm{NiMoS}_{4}{ }^{108}$ and $\mathrm{Cu}_{2} \mathrm{ZnSnS}_{4},{ }^{109,110}$ were extensively studied as CE materials in the DSCs.

\section{Metal nitrides}

Transition metal nitrides are another class of alternative materials that have been tested as CEs in DSCs owing to their low cost, high catalytic activity and good thermal stability. ${ }^{111}$ According to our theoretical prediction, TiN could be catalytically promising for the triiodide reduction reaction because its $E_{\text {ad }}^{\mathrm{I}}$ value was calculated to be $0.65 \mathrm{eV}$, which is within the range of $0.33-1.20 .^{26}$ In 2009 , Jiang et al. ${ }^{112}$ prepared TiN nanotube arrays by the anodization of $\mathrm{Ti}$ foil followed by nitridation in an ammonia atmosphere at $800^{\circ} \mathrm{C}$ for $1 \mathrm{~h}$ and investigated the prepared film as a CE in the DSCs. In the electrochemical impedance spectroscopic measurement, the TiN electrode exhibited an ohmic internal resistance of $5.68 \Omega$ smaller than that of the Pt-FTO electrode $(21.88 \Omega)$. The simulated $R_{c t}$ value for the TiN nanotube arrays electrode was $1.51 \Omega$, which was nearly one-fifth of the value obtained for the Pt-FTO electrode. However, a larger Warburg diffusion impedance was observed because of the higher capacitance developed at the porous electrode/electrolyte interface. To overcome this higher diffusion resistance, the layer thicknesses of the TiN nanotube arrays were suggested to be kept as small as possible for any practical application. The DSC prepared using the TiN nanotube arrays CE had a PCE of 7.73\%, which was relatively higher than that of the Pt-FTO-based DSC (7.45\%). Chen et al. ${ }^{113}$ prepared TiN nanoplates supported with carbon fibers. In their report, they first grew $\mathrm{TiO}_{2}$ nanoplates onto a carbon fibers, and a high-temperature ammonification process was used to convert $\mathrm{TiO}_{2}$ into porous TiN nanoplates, as indicated in Figure 12. The prepared TiN nanoplates supported with carbon fibers acted as the CE material in the DSCs and exhibited a superior PCE $(7.20 \%)$ to that of the $\mathrm{Pt}$ (6.23\%; Figure 12e). Later, TiN composites were investigated as the CE material in the DSCs, and in certain cases, superior performances were achieved because of the synergistic effect of the individual components. ${ }^{114,115}$ According to our theoretical calculation, $\mathrm{Fe}_{2} \mathrm{~N}$ and $\mathrm{MoN}$ could also be used as an active electrocatalyst for the triiodide reduction reaction because their $E_{\text {ad }}^{\mathrm{I}}$ values $(0.77$ and $0.90 \mathrm{eV}$ ) are within the optimal range. Li et al. ${ }^{19}$ evaluated a few typical transition metal nitrides, such as $\mathrm{MoN}, \mathrm{Fe}_{2} \mathrm{~N}$ and $\mathrm{WN}$, which were derived from the nitridation of $\mathrm{MoO}_{2}, \mathrm{Fe}_{2} \mathrm{O}_{3}$ and $\mathrm{WO}_{3}$, respectively. On the basis of electrochemical impedance spectroscopic, the MoN and WN electrode achieved $R_{c t}$ values of 0.92 and 0.94 $\Omega \mathrm{cm}^{2}$, respectively, which were remarkably smaller than that of the $\mathrm{Pt}$ electrode $\left(2.28 \Omega \mathrm{cm}^{2}\right)$, thus exhibiting potential as CE materials. On the other hand, the $\mathrm{Fe}_{2} \mathrm{~N}$ electrode displayed a relatively larger $R_{c t}$ value of $5.45 \Omega \mathrm{cm}^{2}$ and the largest mass-transfer diffusion resistance among all of the electrocatalysts investigated in their study. Eventually, MoN exhibited the highest PCE after Pt, and the PCE order was reported to be $\mathrm{Pt}>\mathrm{MoN}>\mathrm{WN}>\mathrm{Fe}_{2} \mathrm{~N}$. In addition, further improvements on the electrocatalytic performance were conducted by controlling the diffusion kinetics in porous MoN nanorods, and a few composites have also been studied. ${ }^{116}$

\section{Metal carbides}

Transition metal carbides (TMCs) have been studied extensively because of their interesting physicochemical and catalytic properties that are similar to certain noble metals, including $\mathrm{Ru}, \mathrm{Rh}, \mathrm{Pd}$, Os, Ir and Pt. ${ }^{117,118}$ Interestingly, our theoretical calculation results indicated that the $E_{\mathrm{ad}}^{\mathrm{I}}$ values of MoC and WC (estimated to be 0.91 and $1.02 \mathrm{eV}$, respectively) fall within the optimal range of efficient electrocatalysts $(0.33-1.20 \mathrm{eV})$, demonstrating their potential as good electrocatalysts for the triiodide reduction reaction. Jang et al. ${ }^{119}$ initially used WC as a electrocatalyst in the triiodide reduction reaction, and a promising result was obtained. The polymer-derived (WC-PD) and microwaveassisted (WC-MW) products they prepared were tested as CEs in the DSCs, and the PCEs were reported to be 6.61 and $7.01 \%$, respectively, which were slightly lower than that of the conventional Pt-based DSC (8.23\%). Recently, a WC and carbon-composite nanofiber was prepared by electro-spinning followed by a one-step carburization method, and it was demonstrated to be a powerful electrocatalyst in the $I^{-} / I_{3}^{-}$electrolyte system, resulting in the highest PCE of $7.77 \% .^{120}$ A further attempt was made by $\mathrm{Wu}$ et al., ${ }^{17}$ who fabricated the composites of MoC and WC embedded in the ordered nanomesoporous carbon materials (MoC-OMC, WC-OMC). The prepared composites were reported to possess an extremely large surface area of 611 and $598 \mathrm{~m}^{2} \mathrm{~g}^{-1}$ respectively, which was beneficial as a larger contact area for the triiodide reduction reaction during catalysis and 

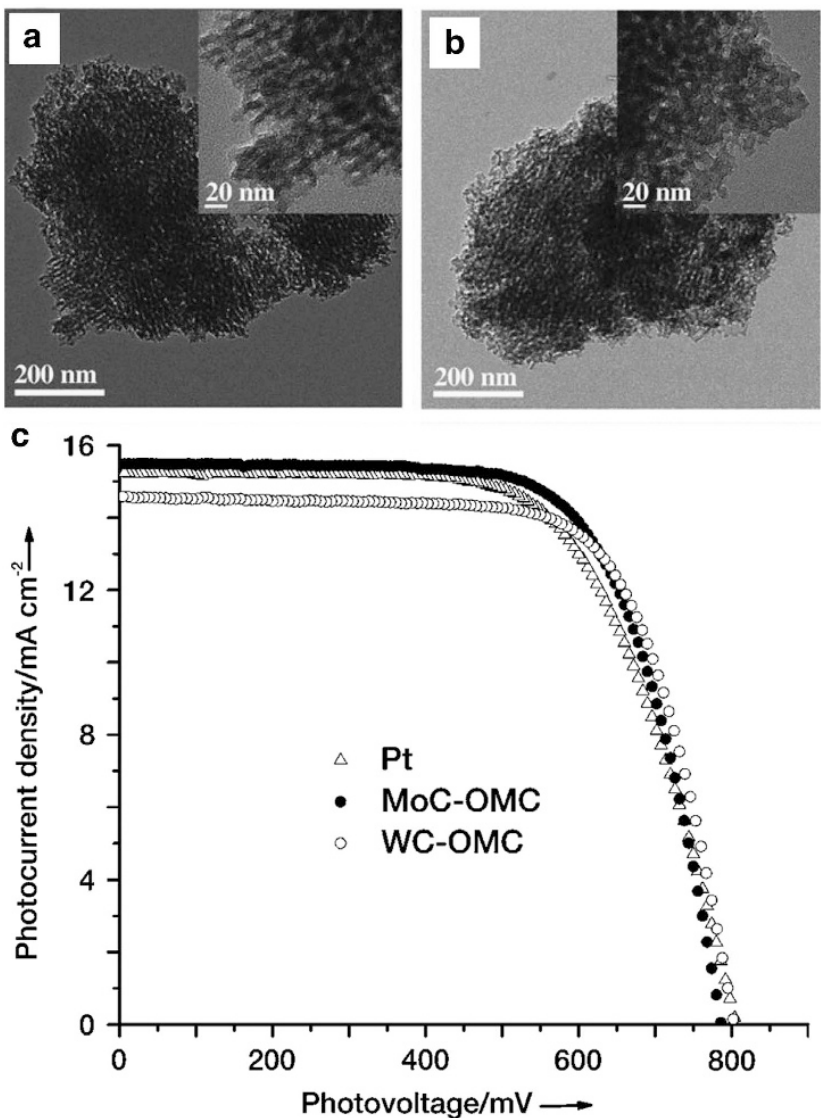

Figure 13 TEM images of (a) MoC and (b) WC embedded in the ordered nanomesoporous carbon $(\mathrm{OMC})$. The insets in $\mathbf{a}$ and $\mathbf{b}$ depict the magnified areas. (c) J-V characteristic curves of the DSCs prepared using WC-OMC, MoC-OMC and Pt CEs. Adapted from Wu et al. ${ }^{17}$ Copyright (C) 2011 WILEYVCH Verlag GmbH \& Co. KGaA, Weinheim.

resulted in superb electrocatalytic activity. The MoC-OMC and WC-OMC were found to produce PCEs of 8.34 and $8.18 \%$, respectively, which is higher than that of the Pt-based DSCs $(7.89 \%$; Figure 13). Then, titanium carbide ${ }^{121}$ and silicon carbide ${ }^{122}$ were also identified to be efficient $\mathrm{CE}$ materials for the triiodide reduction reaction.

Doped metal oxides

The doping treatment on a variety of metal oxides has been proven to be an effective way to improve the electrocatalytic activity for several applications. ${ }^{123,124}$ In the study on DSCs, conductive oxides are primarily used as a conducting support for electrocatalytically active materials (for example, $\mathrm{Pt}$ ) to facilitate a faster electron transfer throughout the external circuit. Unfortunately, a few conductive oxides, such as indium oxide $\left(\mathrm{In}_{2} \mathrm{O}_{3}\right)$, stannic oxide $\left(\mathrm{SnO}_{2}\right)$ and zinc oxide $(\mathrm{ZnO})$, were tested to be catalytically inactive toward the triiodide reduction reaction because of their low-adsorption energy and limited number of active sites. ${ }^{26}$ To enable these materials to be active for the triiodide reduction reaction, $\mathrm{N}$ atoms were purposely incorporated into the $\operatorname{In}_{2} \mathrm{O}_{3}$ nanocrystals. As depicted in Figure 14, the inserted $\mathrm{N}$ atoms formed a local $\mathrm{NO}_{2}{ }^{8-}$, in which two $\mathrm{O}$ atoms deviated from the original lattice site in $\mathrm{In}_{2} \mathrm{O}_{3}$. The doped $\mathrm{N}$ atom preferred to be located at the subsurface and bind with the surface of the In atoms at a distance of $2.30 \AA$. The surface-binding energy of the
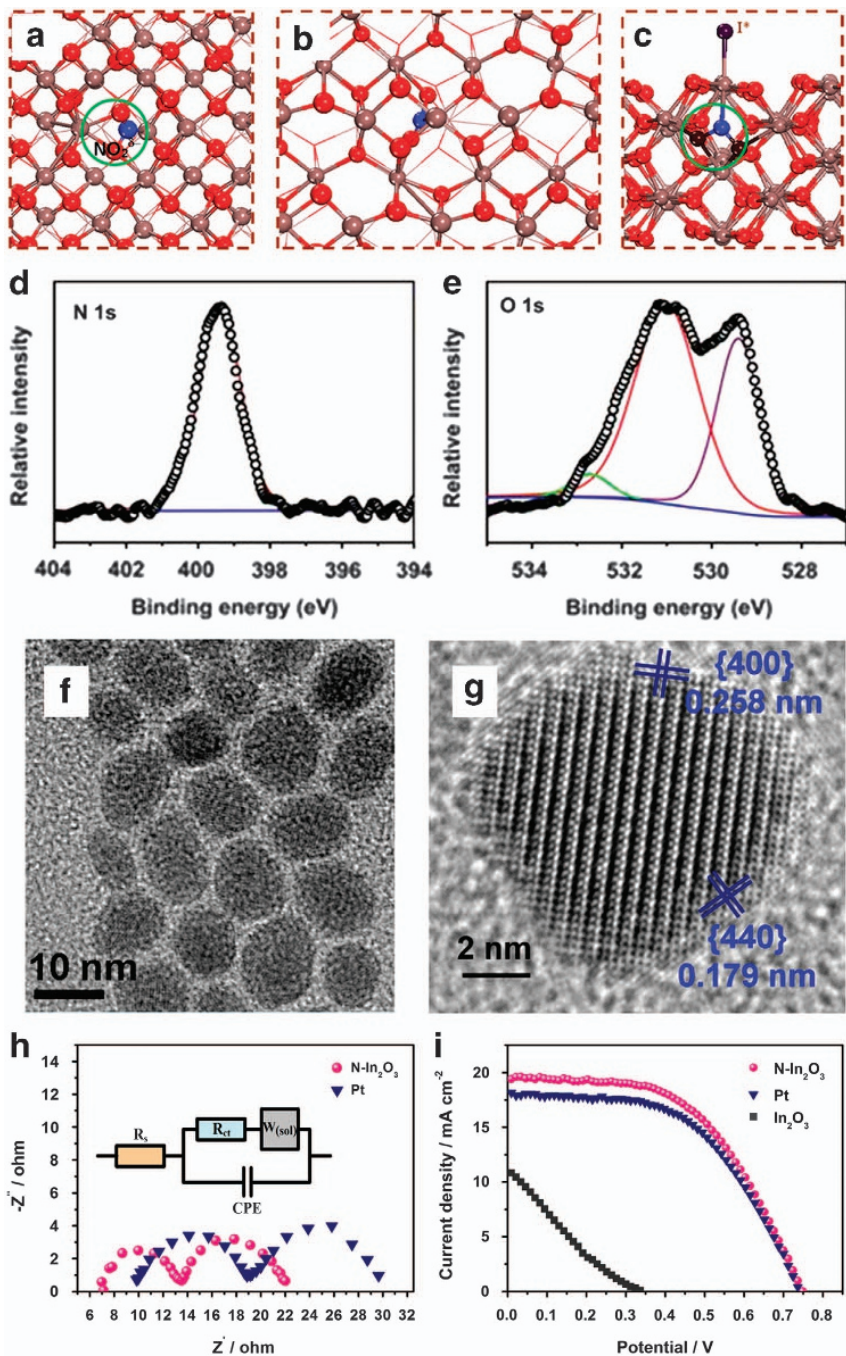

Figure 14 (a) Most stable structure of the interstitial $\mathrm{N}$-doped $\ln _{2} \mathrm{O}_{3}$ $\left(\mathrm{N}-\mathrm{In}_{2} \mathrm{O}_{3}\right)$; (b) top view and (c) side view of the optimized-surface structure of $\mathrm{N}-\mathrm{In}_{2} \mathrm{O}_{3}$. Red, brown, blue and purple balls represent $\mathrm{O}, \mathrm{In}, \mathrm{N}$ and I, respectively. (d, e) High-resolution XPS of $\mathrm{N} 1 \mathrm{~s}, 01 \mathrm{~s}$. (f) TEM and (g) HRTEM images of $\mathrm{N}-\mathrm{In}_{2} \mathrm{O}_{3}$ nanocrystals. (h) Electrochemical impedance spectroscopic spectra of the symmetrical cells prepared using the Pt, $\mathrm{N}-\mathrm{In}_{2} \mathrm{O}_{3}$ and $\mathrm{In}_{2} \mathrm{O}_{3}$ electrocatalysts. (i) $\mathrm{J}-\mathrm{V}$ curves of the DSCs. Adapted from Zhang et al. ${ }^{60}$ Copyright (C) 2013 Rights Managed by Nature Publishing Group.

$\mathrm{N}-\mathrm{In}_{2} \mathrm{O}_{3}$ toward $I$ or $I_{2}$ varied with a change in the coordination environment. Using the DFT calculation, the $E_{\text {ad }}^{\mathrm{I}}$ for $\mathrm{CH}_{3} \mathrm{CN} / \mathrm{N}-\mathrm{In}_{2} \mathrm{O}_{3}$ $(0.94 \mathrm{eV})$ was significantly enhanced compared with that of the pure $\mathrm{In}_{2} \mathrm{O}_{3}(0.16 \mathrm{eV}){ }^{60}$ Clearly, the $E_{\text {ad }}^{\mathrm{I}}$ value of $\mathrm{In}_{2} \mathrm{O}_{3}$ after $\mathrm{N}$ doping is well within the optimal range for a good electrocatalyst, indicating an increased catalytic activity. This theoretically affirmative result encouraged the use of $\mathrm{N}-\mathrm{In}_{2} \mathrm{O}_{3}$ as a CE material in DSCs. ${ }^{60}$ Compared with the undoped $\mathrm{In}_{2} \mathrm{O}_{3}$ counterpart, $\mathrm{N}-\mathrm{In}_{2} \mathrm{O}_{3}$ exhibited remarkable electrocatalytic activity, resulting in a PCE as high as $7.78 \%$, which is higher than that of the DSCs equipped with the Pt CE (Figure 14).

In a recent study, we used a facile in situ vapor-phase hydrothermal surface-doping approach on $\mathrm{Co}_{3} \mathrm{O}_{4}$ nanosheets to achieve an unprecedentedly high surface $\mathrm{S}$ content $(>47 \%)$ and realized a triiodide reduction reaction ability in the DSCs (Figure 15). ${ }^{61}$ The theoretical calculation on the S-doped $\{111\}$ faceted $\mathrm{Co}_{3} \mathrm{O}_{4}$ nanosheets suggested 

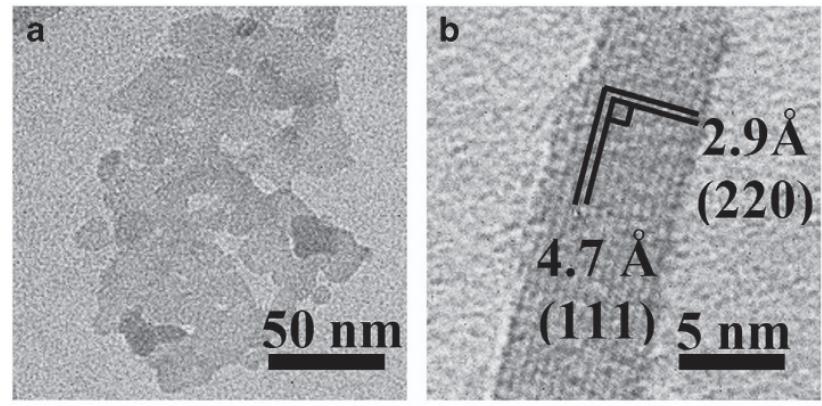

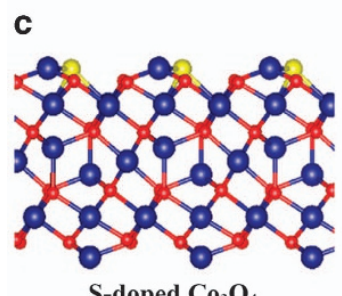

$\mathrm{S}$-doped $\mathrm{Co}_{3} \mathrm{O}_{4}$ (111) surface
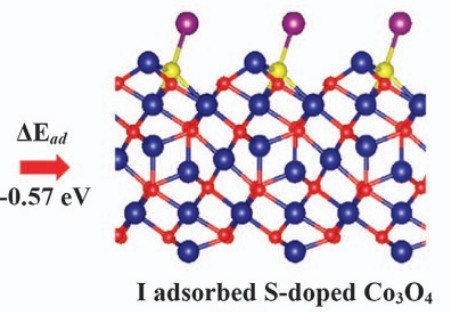

(111) surface
Figure 15 (a) TEM and (b) HRTEM images of the S-doped $\mathrm{Co}_{3} \mathrm{O}_{4}$ nanosheets. (c) Atomic arrangement of the clean and I adsorbed $\{111\}$ faceted surface. Atoms in blue, red, yellow and purple represent Co, O, S and I, respectively. Adapted from Tan et al. ${ }^{61}$ Copyright (C) 2015 Royal Society of Chemistry.

a favorable $E_{\mathrm{ad}}^{\mathrm{I}}$ of $0.57 \mathrm{eV}$, which is close to the value obtained for $\mathrm{Pt}$ $(0.52 \mathrm{eV})$ and expected to be a potential electrocatalyst for the triiodide reduction reaction. The $\mathrm{S}_{-} \mathrm{Co}_{3} \mathrm{O}_{4}$ displayed a competing PCE $(7.79 \%)$ compared with the Pt-based DSC (7.81\%). It is believed that the surface $\mathrm{O}$ substituted with $\mathrm{S}$ led to a $\mathrm{Co}-\mathrm{S}$ bond formation that may promote active sites for the triiodide reduction reaction. In another example, a nitrogen-doped $\mathrm{TiO}_{2} /$ graphene (N-TA/G) nanohybrid prepared at $700{ }^{\circ} \mathrm{C}$ under a continuous flow of ammonia gas was also reported to be a potential CE electrocatalyst for the DSC, exhibiting a PCE of 5.04\%, which was slightly lower than that of the Pt-based DSC $(6.40 \%) .125$

Thus far, we have discussed the development of a generic and efficient screening strategy for the electrocatalytic activity of Pt-free materials for the triiodide reduction reaction with respect to the benchmark Pt electrocatalyst. On the basis of the first-principles calculations, the theoretical screening primarily focused on a few semiconducting materials, including oxides, sulfides, nitrides and carbides, and several of them were predicted to be potentially good candidates as CE materials in DSCs. It is worth mentioning that a few of these inorganic materials have already been proven to possess excellent electrocatalytic activity for the triiodide reduction reaction, and a few of them still deserve to be investigated further. To the best of our knowledge, no specific theoretical investigation is available for certain classes of materials, including phosphides, ${ }^{126}$ selenides, ${ }^{127}$ tellurides, ${ }^{128}$ carbon, ${ }^{129-134}$ polymer ${ }^{135}$ and hybrids, ${ }^{136}$ which are experimentally proven to be active for the triiodide reduction reaction. The authors believe that a comprehensive theoretical model should be developed to categorize a wide variety of materials in a more efficient way.

\section{CONCLUSIONS AND PERSPECTIVES}

As a complex photoelectrochemical device, DSCs are a promising alternative to traditional semiconductor-based solar cells. In this rapidly developing field, finding an active CE material for redox mediators, such as $I^{-} / I_{3}^{-}$, is of great importance for the promotion of the DSCs. Using theoretical calculations, a general principle has been developed for screening Pt-free alternative CE materials for a triiodide reduction reaction in the DSCs, and more importantly, a series of new Pt-free CE materials, such as metals, metal oxides, metal sulfides, metal nitrides and metal carbides, have been successfully prepared, all of which demonstrate an excellent PV performance. With this theoretical screening principle, more low-cost and high-efficiency CE materials are expected to be designed and fabricated through adjusting the local geometrical and electronic structures of certain functional materials. Furthermore, these recent developments in the DSCs' field will pave the way for a large-scale production of the $I^{-} / I_{3}^{-}$ shuttle redox mediator-based DSCs as a commercial product for solar energy conversion. Furthermore, the theoretical framework in this report can be applied to other redox couples, such as Co-complex $(\mathrm{Co}(I I) / \mathrm{Co}(I I I))$, disulfide/thiolate $\left(T^{-} / T_{2}\right)$, ferrocene/ferrocenium $\left(\mathrm{Fc}_{\mathrm{Fc}}{ }^{+}\right), \mathrm{Cu}(\mathrm{I}) / \mathrm{Cu}(\mathrm{II})$ and $\mathrm{Ni}(\mathrm{III}) / \mathrm{Ni}(\mathrm{IV})$ in the DSCs. Interestingly, the screening principle highlighted in this report may offer a promising approach to advance the insight into the inherent electrocatalysis for dye-sensitized photoelectrochemical cells for the hydrogen evolution or synthesis, lithium - iodine $\left(\mathrm{Li}-\mathrm{I}_{2}\right)$ cell for energy storage and two-step photoexcitation for overall water splitting.

\section{CONFLICT OF INTEREST}

The authors declare no conflict of interest.

\section{ACKNOWLEDGEMENTS}

We thank the Australian Research Council (Discovery Project) and the Natural Science Foundation of China for their financial support.

1 O'regan, B. \& Grätzel, M. A low-cost, high-efficiency solar cell based on dye-sensitized colloidal $\mathrm{TiO}_{2}$ films. Nature 353, 737-740 (1991).

2 Grätzel, M. Photoelectrochemical cells. Nature 414, 338-344 (2001).

3 Hagfeldt, A., Boschloo, G., Sun, L., Kloo, L. \& Pettersson, H. Dye-sensitized solar cells. Chem. Rev. 110, 6595-6663 (2010).

4 Zhang, Q., Park, K., Xi, J., Myers, D. \& Cao, G. Recent progress in dye-sensitized solar cells using nanocrystallite aggregates. Adv. Energy Mater. 1, 988-1001 (2011)

5 Ondersma, J. W. \& Hamann, T. W. Recombination and redox couples in dye-sensitized solar cells. Coord. Chem. Rev. 257, 1533-1543 (2013).

6 Kavan, L., Yum, J. H., Nazeeruddin, M. K. \& Grätzel, M. Graphene nanoplatelet cathode for $\mathrm{Co}(\mathrm{III}) /(\mathrm{II})$ mediated dye-sensitized solar cells. ACS Nano 5, 9171-9178 (2011).

7 Yella, A., Lee, H. W., Tsao, H. N., Yi, C., Chandiran, A. K., Nazeeruddin, M. K., Diau, E. W. G., Yeh, C. Y., Zakeeruddin, S. M. \& Grätzel, M. Porphyrin-sensitized solar cells with cobalt (II/III)-based redox electrolyte exceed 12 percent efficiency. Science 334, 629-634 (2011).

8 Yun, S., Hagfeldt, A. \& Ma, T. Pt-free counter electrode for dye-sensitized solar cells with high efficiency. Adv. Mater. 26, 6210-6237 (2014).

9 Thomas, S., Deepak, T. G., Anjusree, G. S., Arun, T. A., Nair, S. V. \& Nair, A. S. A review on counter electrode materials in dye-sensitized solar cells. J. Mater. Chem. A 2, 4474-4490 (2014).

10 Wei, W., Wang, H. \& Hu, Y. H. A review on PEDOT-based counter electrodes for dye-sensitized solar cells. Int. J. Energy Res. 38, 1099-1111 (2014).

$11 \mathrm{Wu}, \mathrm{M}$. \& Ma, T. Recent progress of counter electrode catalysts in dye-sensitized solar cells. J. Phys. Chem. C 118, 16727-16742 (2014).

12 Poudel, P. \& Qiao, Q. Carbon nanostructure counter electrodes for low cost and stable dye-sensitized solar cells. Nano Energy 4, 157-175 (2014).

13 Murakami, T. N. \& Grätzel, M. Counter electrodes for DSC: application of functional materials as catalysts. Inorg. Chim. Acta. 361, 572-580 (2008).

14 Hwang, S., Batmunkh, M., Nine, M. J., Chung, H. \& Jeong, H. Dye-sensitized sola cell counter electrodes based on carbon nanotubes. ChemPhysChem 16 53-65 (2015).

$15 \mathrm{Wu}, \mathrm{M}$. \& Ma, T. Platinum-free catalysts as counter electrodes in dye-sensitized solar cells. ChemSusChem 5, 1343-1357 (2012).

16 Wang, M., Anghel, A. M., Marsan, B. t., Cevey, Ha, N. L., Pootrakulchote, N., Zakeeruddin, S. M. \& Grätzel, M. CoS supersedes Pt as efficient electrocatalyst for triiodide reduction in dye-sensitized solar cells. J. Am. Chem. Soc. 131, 15976-15977 (2009).

17 Wu, M., Lin, X., Hagfeldt, A. \& Ma, T. Low-cost molybdenum carbide and tungsten carbide counter electrodes for dye-sensitized solar cells. Angew. Chem. Int. Ed. 50, 3520-3524 (2011). 
18 Wu, M., Lin, X., Wang, Y., Wang, L., Guo, W., Qi, D., Peng, X., Hagfeldt, A., Grätzel, M. \& Ma, T. Economical Pt-free catalysts for counter electrodes of dye-sensitized solar cells. J. Am. Chem. Soc. 134, 3419-3428 (2012).

19 Li, G. R., Song, J., Pan, G. L. \& Gao, X. P. Highly Pt-like electrocatalytic activity of transition metal nitrides for dye-sensitized solar cells. Energy Environ. Sci. 4 1680-1683 (2011)

20 Kay, A. \& Grätzel, M. Low cost photovoltaic modules based on dye sensitized nanocrystalline titanium dioxide and carbon powder. Sol. Energy Mater. Sol. Cells. 44, 99-117 (1996).

21 Trancik, J. E., Barton, S. C. \& Hone, J. Transparent and catalytic carbon nanotube films. Nano Lett. 8, 982-987 (2008).

22 Shibata, Y., Kato, T., Kado, T., Shiratuchi, R., Takashima, W., Kaneto, K. \& Hayase, S. Quasi-solid dye sensitised solar cells filled with ionic liquid-increase in efficiencies by specific interaction between conductive polymers and gelators. Chem. Commun. 2730-2731 (2003)

23 Ahmad, S., Yum, J. H., Butt, H. J., Nazeeruddin, M. K. \& Grätzel, M. Efficient platinum-free counter electrodes for dye-sensitized solar cell applications. ChemPhysChem 11, 2814-2819 (2010).

24 Yue, G., Wu, J., Xiao, Y., Huang, M., Lin, J. \& Lin, J. Y. High performance platinumfree counter electrode of molybdenum sulfide-carbon used in dye-sensitized solar cells. J. Mater. Chem. A 1, 1495-1501 (2013).

25 Yi, L., Liu, Y., Yang, N., Tang, Z., Zhao, H., Ma, G., Su, Z. \& Wang, D. One dimensional CulnS $_{2}-\mathrm{ZnS}$ heterostructured nanomaterials as low-cost and highperformance counter electrodes of dye-sensitized solar cells. Energy Environ. Sci. 6 , 835-840 (2013).

26 Hou, Y., Wang, D., Yang, X. H., Fang, W. Q., Zhang, B., Wang, H. F., Lu, G. Z., Hu, P., Zhao, H. J. \& Yang, H. G. Rational screening low-cost counter electrodes for dyesensitized solar cells. Nat. Commun. 4, 1583 (2013).

27 Ardo, S. \& Meyer, G. J. Photodriven heterogeneous charge transfer with transitionmetal compounds anchored to $\mathrm{TiO}_{2}$ semiconductor surfaces. Chem. Soc. Rev. 38, 115-164 (2009)

28 Halme, J., Vahermaa, P., Miettunen, K. \& Lund, P. Device physics of dye solar cells. Adv. Energy Mater. 22, E210-E234 (2010)

29 Nazeeruddin, M. K., De Angelis, F., Fantacci, S., Selloni, A., Viscardi, G., Liska, P., Ito, S., Takeru, B. \& Grätzel, M. Combined experimental and DFT-TDDFT computational study of photoelectrochemical cell ruthenium sensitizers. J. Am. Chem. Soc. 127, 16835-16847 (2005).

30 Tiwana, $\mathrm{P}$. Docampo, $\mathrm{P}$, Johnston, M. B., Snaith, $\mathrm{H}$.J. \& Herz, L. M. Electron mobility and injection dynamics in mesoporous $\mathrm{ZnO}, \mathrm{SnO}_{2}$, and $\mathrm{TiO}_{2}$ films used in dye-sensitized solar cells. ACS Nano 5, 5158-5166 (2011)

31 Saito, M. \& Fujihara, S. Large photocurrent generation in dye-sensitized ZnO solar cells. Energy Environ. Sci. 1, 280-283 (2008).

32 Sayama, K., Sugihara, H. \& Arakawa, H. Photoelectrochemical properties of a porous $\mathrm{Nb}_{2} \mathrm{O}_{5}$ electrode sensitized by a ruthenium dye. Chem. Mater. 10, 3825-3832 (1998).

33 Yamanaka, N., Kawano, R., Kubo, W., Kitamura, T., Wada, Y., Watanabe, M. \& Yanagida, S. Ionic liquid crystal as a hole transport layer of dye-sensitized solar cells. Chem. Commun. 740-742 (2005)

34 Nogueira, A. F., Durrant, J. R. \& De Paoli, M. A. Dye-sensitized nanocrystalline solar cells employing a polymer electrolyte. Adv. Mater. 13, 826-830 (2001).

35 Stergiopoulos, T., Arabatzis, I. M., Katsaros, G. \& Falaras, P. Binary polyethylene oxide/titania solid-state redox electrolyte for highly efficient nanocrystalline $\mathrm{TiO}_{2}$ photoelectrochemical cells. Nano Lett. 2, 1259-1261 (2002)

36 Feldt, S. M., Gibson, E. A., Gabrielsson, E., Sun, L., Boschloo, G. \& Hagfeldt, A. Design of organic dyes and cobalt polypyridine redox mediators for high-efficiency dyesensitized solar cells. J. Am. Chem. Soc. 132, 16714-16724 (2010).

37 Wang, M., Chamberland, N., Breau, L., Moser, J. E., Humphry-Baker, R., Marsan, B., Zakeeruddin, S. M. \& Grätzel, M. An organic redox electrolyte to rival triiodide/iodide in dye-sensitized solar cells. Nat. Chem. 2, 385-389 (2010).

38 Daeneke, T., Kwon, T. H., Holmes, A. B., Duffy, N. W., Bach, U. \& Spiccia, L. Highefficiency dye-sensitized solar cells with ferrocene-based electrolytes. Nat. Chem. $\mathbf{3}$, 211-215 (2011)

39 Bai, Y., Yu, Q., Cai, N., Wang, Y., Zhang, M. \& Wang, P. High-efficiency organic dyesensitized mesoscopic solar cells with a copper redox shuttle. Chem. Commun. 47, 4376-4378 (2011)

40 Li, T. C., Spokoyny, A. M., She, C., Farha, O. K., Mirkin, C. A., Marks, T. J. \& Hupp, J. $\mathrm{T}$. $\mathrm{Ni}(\mathrm{III}) /(\mathrm{IV})$ bis(dicarbollide) as a fast, noncorrosive redox shuttle for dye-sensitized solar cells. J. Am. Chem. Soc. 132, 4580-4582 (2010).

41 Hamann, T. W. The end of iodide? Cobalt complex redox shuttles in DSSCs. Dalton Trans. 41, 3111-3115 (2012).

42 Wang, M., Gratzel, C., Zakeeruddin, S. M. \& Gratzel, M. Recent developments in redox electrolytes for dye-sensitized solar cells. Energy Environ. Sci. 5, 9394-9405 (2012).

43 Wu, J., Lan, Z., Lin, J., Huang, M., Huang, Y., Fan, L. \& Luo, G. Electrolytes in dyesensitized solar cells. Chem. Rev. 115, 2136-2173 (2015).

44 Hohenberg, P. \& Kohn, W. Inhomogeneous electron gas. Phys. Rev. 136, B864-B871 (1964)

45 Hyman, M. P. \& Medlin, J. W. Mechanistic study of the electrochemical oxygen reduction reaction on $\mathrm{Pt}(111)$ using density functional theory. J. Phys. Chem. B 110 15338-15344 (2006)

46 Karlberg, G. S., Rossmeisl, J. \& Norskov, J. K. Estimations of electric field effects on the oxygen reduction reaction based on the density functional theory. Phys. Chem. Chem. Phys. 9, 5158-5161 (2007).
47 Greeley, J., Jaramillo, T. F., Bonde, J., Chorkendorff, I. \& Norskov, J. K. Computational high-throughput screening of electrocatalytic materials for hydrogen evolution. Nat. Mater. 5, 909-913 (2006).

48 Labat, F., Le Bahers, T., Ciofini, I. \& Adamo, C. First-principles modeling of dye-sensitized solar cells: challenges and perspectives. Acc. Chem. Res. 45, 1268-1277 (2012)

49 Prezhdo, O. V., Duncan, W. R. \& Prezhdo, V. V. Dynamics of the photoexcited electron at the chromophore-semiconductor interface. Acc. Chem. Res. 41, 339-348 (2008).

50 Martsinovich, N. \& Troisi, A. Theoretical studies of dye-sensitised solar cells: from electronic structure to elementary processes. Energy Environ. Sci. 4 4473-4495 (2011)

51 Hauch, A. \& Georg, A. Diffusion in the electrolyte and charge-transfer reaction at the platinum electrode in dye-sensitized solar cells. Electrochim. Acta. 46 , 3457-3466 (2001)

52 Wang, H., Guo, Y., Lu, G. \& Hu, P. An understanding and implications of the coverage of surface free sites in heterogeneous catalysis. J. Chem. Phys. 130, 224701 (2009).

53 Cheng, J., Hu, P., Ellis, P., French, S., Kelly, G. \& Lok, C. M. Brønsted-Evans Polanyi relation of multistep reactions and volcano curve in heterogeneous catalysis. J. Phys. Chem. C 112, 1308-1311 (2008).

54 Kelly, C. P., Cramer, C. J. \& Truhlar, D. G. Single-ion solvation free energies and the normal hydrogen electrode potential in methanol, acetonitrile, and dimethyl sulfoxide. J. Phys. Chem. B. 111, 408-422 (2007).

55 Crawford, E., Mclndoe, J. S. \& Tuck, D. G. The energetics of the $X_{2}+X^{-} \rightarrow X_{3}$ equilibrium $(X=\mathrm{Cl}, \mathrm{Br}, \mathrm{I})$ in aqueous and nonaqueous solution. Can. J. Chem. $\mathbf{8 4}$, 1607-1613 (2006)

56 Cheng, J. \& Hu, P. Theory of the kinetics of chemical potentials in heterogeneous catalysis. Angew. Chem. Int. Ed. 50, 7650-7654 (2011).

57 Kudo, A. \& Miseki, Y. Heterogeneous photocatalyst materials for water splitting. Chem. Soc. Rev. 38, 253-278 (2009).

58 Zhang, B., Wang, D., Hou, Y., Yang, S., Yang, X. H., Zhong, J. H., Liu, J., Wang, H. F., Hu, P., Zhao, H. J. \& Yang, H. G. Facet-dependent catalytic activity of platinum nanocrystals for triiodide reduction in dye-sensitized solar cells. Sci. Rep. 3, 1836 (2013).

59 Hou, Y., Chen, Z. P., Wang, D., Zhang, B., Yang, S., Wang, H. F., Hu, P., Zhao, H. J. \& Yang, H. G. Highly electrocatalytic activity of $\mathrm{RuO}_{2}$ nanocrystals for triiodide reduction in dye-sensitized solar cells. Small 10, 484-492 (2014).

60 Zhang, B., Zhang, N. N., Chen, J. F., Hou, Y., Yang, S., Guo, J. W., Yang, X. H., Zhong, J. H., Wang, H. F., Hu, P., Zhao, H. J. \& Yang, H. G. Turning indium oxide into a superior electrocatalyst: deterministic heteroatoms. Sci. Rep. 3, 3109 (2013).

61 Tan, Z., Liu, P., Zhang, H., Wang, Y., Al-Mamun, M., Yang, H. G., Wang, D., Tang, Z. \& Zhao, $\mathrm{H}$. An in situ vapour phase hydrothermal surface doping approach for fabrication of high performance $\mathrm{CO}_{3} \mathrm{O}_{4}$ electrocatalysts with an exceptionally high S-doped active surface. Chem. Commun. 51, 5695-5697 (2015).

62 Li, Y., Wang, H., Zhang, H., Liu, P., Wang, Y., Fang, W., Yang, H., Li, Y. \& Zhao, H. A $\{0001\}$ faceted single crystal NiS nanosheet electrocatalyst for dye-sensitised solar cells: sulfur-vacancy induced electrocatalytic activity. Chem. Commun. 50, 5569-5571 (2014).

63 Wang, C., Daimon, H., Onodera, T., Koda, T. \& Sun, S. A general approach to the sizeand shape-controlled synthesis of platinum nanoparticles and their catalytic reduction of oxygen. Angew. Chem. Int. Ed. 47, 3588-3591 (2008).

64 Sheng, W., Gasteiger, H. A. \& Shao-Horn, Y. Hydrogen oxidation and evolution reaction kinetics on platinum: acid vs alkaline electrolytes. J. Electrochem. Soc. 157, B1529-B1536 (2010).

65 Bond, G. C. Supported metal catalysts: some unsolved problems. Chem. Soc. Rev. 20 441-475 (1991).

66 Narayanan, R. \& El-Sayed, M. A. Effect of catalytic activity on the metallic nanoparticle size distribution: electron-transfer reaction between $\mathrm{Fe}(\mathrm{CN})_{6}$ and thiosulfate ions catalyzed by PVP-platinum nanoparticles. J. Phys. Chem. B 107 , 12416-12424 (2003)

67 Huang, X., Zhao, Z., Fan, J., Tan, Y. \& Zheng, N. Amine-assisted synthesis of concave polyhedral platinum nanocrystals having $\{411\}$ high-index facets. J. Am. Chem. Soc. 133, 4718-4721 (2011)

$68 \mathrm{Wu}$, J., Gross, A. \& Yang, H. Shape and composition-controlled platinum alloy nanocrystals using carbon monoxide as reducing agent. Nano Lett. 11, 798-802 (2011)

69 Hsieh, T. L., Chen, H. W., Kung, C. W., Wang, C. C., Vittal, R. \& Ho, K. C. A highly efficient dye-sensitized solar cell with a platinum nanoflowers counter electrode. $J$. Mater. Chem. 22, 5550-5559 (2012).

70 Zhang, H., Zhou, W., Du, Y., Yang, P. \& Wang, C. One-step electrodeposition of platinum nanoflowers and their high efficient catalytic activity for methanol electrooxidation. Electrochem. Commun. 12, 882-885 (2010).

71 Yang, W., Wang, Y., Li, J. \& Yang, X. Polymer wrapping technique: an effective route to prepare Pt nanoflower/carbon nanotube hybrids and application in oxygen reduction. Energy Environ. Sci. 3, 144-149 (2010).

72 Kawasaki, H., Yao, T., Suganuma, T., Okumura, K., Iwaki, Y., Yonezawa, T., Kikuchi, T. \& Arakawa, R. Platinum nanoflowers on scratched silicon by galvanic displacement for an effective SALDI substrate. Chem. Eur. J. 16, 10832-10843 (2010).

73 Jeong, H., Pak, Y., Hwang, Y., Song, H., Lee, K. H., Ko, H. C. \& Jung, G. Y. Enhancing the charge transfer of the counter electrode in dye-sensitized solar cells using periodically aligned platinum nanocups. Small 8, 3757-3761 (2012).

74 Wu, M., Zhang, Q., Xiao, J., Ma, C., Lin, X., Miao, C., He, Y., Gao, Y., Hagfeldt, A. \& $\mathrm{Ma}, \mathrm{T}$. Two flexible counter electrodes based on molybdenum and tungsten nitrides for dye-sensitized solar cells. J. Mater. Chem. 21, 10761-10766 (2011). 
75 Zheng, H., Tachibana, Y. \& Kalantar-zadeh, K. Dye-sensitized solar cells based on $\mathrm{WO}_{3}$. Langmuir 26, 19148-19152 (2010).

76 Wang, H., Wei, W. \& Hu, Y. H. NiO as an efficient counter electrode catalyst for dyesensitized solar cells. Top. Catal. 57, 607-611 (2014).

77 Wang, H., Wei, W. \& Hu, Y. H. Efficient ZnO-based counter electrodes for dyesensitized solar cells. J. Mater. Chem. A 1, 6622-6628 (2013).

78 Lee, Y., Suntivich, J., May, K. J., Perry, E. E. \& Shao-Horn, Y. Synthesis and activities of rutile $\mathrm{IrO}_{2}$ and $\mathrm{RuO}_{2}$ nanoparticles for oxygen evolution in acid and alkaline solutions. J. Phys. Chem. Lett. 3, 399-404 (2012).

79 Fernández, C., Sassoye, C., Flores, N., Escalona, N., Gaigneaux, E. M., Sanchez, C. \& Ruiz, P. Insights in the mechanism of deposition and growth of $\mathrm{RuO}_{2}$ colloidal nanoparticles over alumina. Implications on the activity for ammonia synthesis. Appl. Catal. A Gen. 502, 48-56 (2015)

80 Papageorgiou, N. Counter-electrode function in nanocrystalline photoelectrochemical cell configurations. Coord. Chem. Rev. 248, 1421-1446 (2004).

81 Wu, M., Lin, X., Hagfeldt, A. \& Ma, T. A novel catalyst of $\mathrm{WO}_{2}$ nanorod for the counter electrode of dye-sensitized solar cells. Chem. Commun. 47, 4535-4537 (2011).

82 Cheng, L., Hou, Y., Zhang, B., Yang, S., Guo, J. W., Wu, L. \& Yang, H. G. Hydrogentreated commercial $\mathrm{WO}_{3}$ as an efficient electrocatalyst for triiodide reduction in dyesensitized solar cells. Chem. Commun. 49, 5945-5947 (2013).

83 Zhou, H., Shi, Y., Dong, Q., Wang, Y., Zhu, C., Wang, L., Wang, N., Wei, Y., Tao, S. \& $\mathrm{Ma}, \mathrm{T}$. Interlaced $\mathrm{W}_{18} \mathrm{O}_{49}$ nanofibers as a superior catalyst for the counter electrode of highly efficient dye-sensitized solar cells. J. Mater. Chem. A 2, 4347-4354 (2014).

84 Yun, S., Pu, H., Chen, J., Hagfeldt, A. \& Ma, T. Enhanced performance of supported $\mathrm{HfO}_{2}$ counter electrodes for redox couples used in dye-sensitized solar cells. ChemSusChem 7, 442-450 (2014).

85 Guo, M., Tang, B., Zhang, H., Yin, S., Jiang, W., Zhang, Y., Li, M., Wang, H. \& Jiao, L. A high efficiency $\mathrm{CoCr}_{2} \mathrm{O}_{4}$ /carbon nanotubes nanocomposite electrocatalyst for dyesensitised solar cells. Chem. Commun. 50, 7356-7358 (2014).

86 Lin, J. Y., Liao, J. H. \& Chou, S. W. Cathodic electrodeposition of highly porous cobalt sulfide counter electrodes for dye-sensitized solar cells. Electrochim. Acta 56, 8818-8826 (2011).

87 Kung, C. W., Chen, H. W., Lin, C. Y., Huang, K. C., Vittal, R. \& Ho, K. C. CoS acicular nanorod arrays for the counter electrode of an efficient dye-sensitized solar cell. ACS Nano 6, 7016-7025 (2012).

88 Hsu, S. H., Li, C. T., Chien, H. T., Salunkhe, R. R., Suzuki, N., Yamauchi, Y., Ho, K. C. \& Wu, K. C. W. Platinum-free counter electrode comprised of metal-organicframework (MOF)-derived cobalt sulfide nanoparticles for efficient dye-sensitized solar cells (DSSCs). Sci. Rep. 4, 6983 (2014).

89 Bi, H., Zhao, W., Sun, S., Cui, H., Lin, T., Huang, F., Xie, X. \& Jiang, M. Graphene films decorated with metal sulfide nanoparticles for use as counter electrodes of dyesensitized solar cells. Carbon 61, 116-123 (2013).

90 Xiao, Y., Wu, J., Lin, J. Y., Tai, S. Y. \& Yue, G. Pulse electrodeposition of CoS on MWCNT/Ti as a high performance counter electrode for a Pt-free dye-sensitized solar cell. J. Mater. Chem. A 1, 1289-1295 (2013).

91 Sudhagar, P., Nagarajan, S., Lee, Y. G., Song, D., Son, T., Cho, W., Heo, M., Lee, K., Won, J. \& Kang, Y. S. Synergistic catalytic effect of a composite (CoS/PEDOT:PSS) counter electrode on triiodide reduction in dye-sensitized solar cells. ACS Appl. Mater. Interfaces 3, 1838-1843 (2011).

92 Zhao, W., Lin, T., Sun, S., Bi, H., Chen, P., Wan, D. \& Huang, F. Oriented singlecrystalline nickel sulfide nanorod arrays: "two-in-one" counter electrodes for dyesensitized solar cells. J. Mater. Chem. A 1, 194-198 (2013).

93 Xiao, Y., Wu, J., Lin, J., Yue, G., Lin, J., Huang, M., Huang, Y., Lan, Z. \& Fan, L. A high performance Pt-free counter electrode of nickel sulfide/multi-wall carbon nanotube/titanium used in dye-sensitized solar cells. J. Mater. Chem. A 1, 13885-13889 (2013).

94 Hu, Y., Zheng, Z., Jia, H., Tang, Y. \& Zhang, L. Selective synthesis of FeS and FeS nanosheet films on iron substrates as novel photocathodes for tandem dye-sensitized solar cells. J. Phys. Chem. C 112, 13037-13042 (2008).

95 Laursen, A. B., Kegnæs, S., Dahl, S. \& Chorkendorff, I. Molybdenum sulfides-efficient and viable materials for electro-and photoelectrocatalytic hydrogen evolution. Energy Environ. Sci. 5, 5577-5591 (2012)

96 Wu, M., Wang, Y., Lin, X., Yu, N., Wang, L., Wang, L., Hagfeldt, A. \& Ma, T. Economical and effective sulfide catalysts for dye-sensitized solar cells as counter electrodes. Phys. Chem. Chem. Phys. 13, 19298-19301 (2011).

97 Al-Mamun, M., Zhang, H., Liu, P., Wang, Y., Cao, J. \& Zhao, H. Directly hydrothermal growth of ultrathin $\mathrm{MoS}_{2}$ nanostructured films as high performance counter electrodes for dye-sensitised solar cells. RSC Adv. 4, 21277-21283 (2014).

98 Chang, S. H., Lu, M. D., Tung, Y. L. \& Tuan, H. Y. Gram-scale synthesis of catalytic $\mathrm{Cog}_{8}$ nanocrystal ink as a cathode material for spray-deposited, large-area dyesensitized solar cells. ACS Nano 7, 9443-9451 (2013).

99 Yang, J., Bao, C., Zhu, K., Yu, T., Li, F., Liu, J., Li, Z. \& Zou, Z. High catalytic activity and stability of nickel sulfide and cobalt sulfide hierarchical nanospheres on the counter electrodes for dye-sensitized solar cells. Chem. Commun. 50, 4824-4826 (2014)

100 Zhang, H., Yang, L., Liu, Z., Ge, M., Zhou, Z., Chen, W., Li, Q. \& Liu, L. Facetdependent activity of bismuth sulfide as low-cost counter-electrode materials for dyesensitized solar cells. J. Mater. Chem. 22, 18572-18577 (2012).

101 Chen, X., Hou, Y., Zhang, B., Yang, X. H. \& Yang, H. G. Low-cost SnS counte electrodes for dye-sensitized solar cells. Chem. Commun. 49, 5793-5795 (2013).

102 Zhang, H., Ge, M., Yang, L., Zhou, Z., Chen, W., Li, Q. \& Liu, L. Synthesis and catalytic properties of $\mathrm{Sb}_{2} \mathrm{~S}_{3}$ nanowire bundles as counter electrodes for dye-sensitized solar cells. J. Phys. Chem. C 117, 10285-10290 (2013).
103 Wang, Y. C., Wang, D. Y., Jiang, Y. T., Chen, H. A., Chen, C. C., Ho, K. C., Chou, H. L. \& Chen, C. W. FeS 2 nanocrystal ink as a catalytic electrode for dye-sensitized solar cells. Angew. Chem. Int. Ed. 52, 6694-6698 (2013)

104 Yue, G., Wu, J., Lin, J. Y., Xiao, Y., Tai, S. Y., Lin, J., Huang, M. \& Lan, Z. A counte electrode of multi-wall carbon nanotubes decorated with tungsten sulfide used in dyesensitized solar cells. Carbon 55, 1-9 (2013).

105 Li, C. T., Lee, C. P., Li, Y. Y., Yeh, M. H. \& Ho, K. C. A composite film of TiS $2 /$ PEDOT PSS as the electrocatalyst for the counter electrode in dye-sensitized solar cells. J. Mater. Chem. A 1, 14888-14896 (2013).

106 Yang, J., Bao, C., Zhang, J., Yu, T., Huang, H., Wei, Y., Gao, H., Fu, G., Liu, J. \& Zou Z. In situ grown vertically oriented $\mathrm{CuInS}_{2}$ nanosheets and their high catalytic activity as counter electrodes in dye-sensitized solar cells. Chem. Commun. 49, 2028-2030 (2013).

107 Lin, J. Y. \& Chou, S. W. Highly transparent $\mathrm{NiC}_{2} \mathrm{~S}_{4}$ thin film as an effective catalyst toward triiodide reduction in dye-sensitized solar cells. Electrochem. Commun. 37, 11-14 (2013)

108 Zheng, X., Guo, J., Shi, Y., Xiong, F., Zhang, W. H., Ma, T. \& Li, C. Low-cost and highperformance $\mathrm{CoMoS}_{4}$ and $\mathrm{NiMoS}_{4}$ counter electrodes for dye-sensitized solar cells. Chem. Commun. 49, 9645-9647 (2013).

109 Wang, J., Xin, X. \& Lin, Z. $\mathrm{Cu}_{2} \mathrm{ZnSnS}_{4}$ nanocrystals and graphene quantum dots for photovoltaics. Nanoscale 3, 3040-3048 (2011).

110 Xin, X., He, M., Han, W., Jung, J. \& Lin, Z. Low-cost copper zinc tin sulfide counte electrodes for high-efficiency dye-sensitized solar cells. Angew. Chem. Int. Ed. 50, 11739-11742 (2011).

111 Wei, W., Wang, H. \& Hu, Y. H. Unusual particle-size-induced promoter-to-poison transition of $\mathrm{ZrN}$ in counter electrodes for dye-sensitized solar cells. J. Mater. Chem. A 1, 14350-14357 (2013).

112 Jiang, Q. W., Li, G. R. \& Gao, X. P. Highly ordered TiN nanotube arrays as counter electrodes for dye-sensitized solar cells. Chem. Commun. 44, 6720-6722 (2009).

113 Chen, L., Dai, H., Zhou, Y., Hu, Y., Yu, T., Liu, J. \& Zou, Z. Porous, single crystalline titanium nitride nanoplates grown on carbon fibers: excellent counter electrodes for low-cost, high performance, fiber-shaped dye-sensitized solar cells. Chem. Commun. 50, 14321-14324 (2014).

114 Li, G. R., Wang, F., Jiang, Q. W., Gao, X. P. \& Shen, P. W. Carbon nanotubes with titanium nitride as a low-cost counter-electrode material for dye-sensitized solar cells. Angew. Chem. Int. Ed. 49, 3653-3656 (2010).

115 Xu, H., Zhang, X., Zhang, C., Liu, Z., Zhou, X., Pang, S., Chen, X., Dong, S., Zhang, Z. Zhang, L., Han, P., Wang, X. \& Cui, G. Nanostructured titanium nitride/PEDOT:PSS composite films as counter electrodes of dye-sensitized solar cells. ACS Appl. Mater. Interfaces 4, 1087-1092 (2012).

116 Song, J., Li, G. R., Xi, K., Lei, B., Gao, X. P. \& Kumar, R. V. Enhancement of diffusion kinetics in porous MoN nanorods-based counter electrode in a dye-sensitized solar cell. J. Mater. Chem. A 2, 10041-10047 (2014).

117 Hwu, H. H. \& Chen, J. G. Surface chemistry of transition metal carbides. Chem. Rev. 105, 185-212 (2005).

118 Sun, J., Zheng, M., Wang, X., Wang, A., Cheng, R., Li, T. \& Zhang, T. Catalytic performance of activated carbon supported tungsten carbide for hydrazine decomposition. Catal. Lett. 123, 150-155 (2008).

119 Jang, J. S., Ham, D. J., Ramasamy, E., Lee, J. \& Lee, J. S. Platinum-free tungsten carbides as an efficient counter electrode for dye sensitized solar cells. Chem Commun. 46, 8600-8602 (2010).

120 Jeong, I., Lee, J., Vincent Joseph, K. L., Lee, H. I., Kim, J. K., Yoon, S. \& Lee, J. Low cost electrospun WC/C composite nanofiber as a powerful platinum-free counter electrode for dye sensitized solar cell. Nano Energy 9, 392-400 (2014).

121 Wang, Y., Wu, M., Lin, X., Shi, Z., Hagfeldt, A. \& Ma, T. Several highly efficient catalysts for Pt-free and FTO-free counter electrodes of dye-sensitized solar cells. J. Mater. Chem. 22, 4009-4014 (2012).

122 Tsai, Y. L., Li, C. T., Huang, T. Y., Lee, C. T., Lin, C. Y., Chu, C. W., Vittal, R. \& Ho, K. C. Electrocatalytic SiC nanoparticles/PEDOT:PSS composite thin films as the counter electrodes of dye-sensitized solar cells. ChemElectroChem 1 1031-1039 (2014).

123 Nah, Y. C., Paramasivam, I. \& Schmuki, P. Doped $\mathrm{TiO}_{2}$ and $\mathrm{TiO}_{2}$ nanotubes: synthesis and applications. ChemPhysChem 11, 2698-2713 (2010).

124 Reyes-Gil, K. R., Reyes-García, E. A. \& Raftery, D. Nitrogen-doped $\ln _{2} \mathrm{O}_{3}$ thin film electrodes for photocatalytic water splitting. J. Phys. Chem. C 111 14579-14588 (2007)

125 Wang, R., Wu, Q., Lu, Y., Liu, H., Xia, Y., Liu, J., Yang, D., Huo, Z. \& Yao, X Preparation of nitrogen-doped $\mathrm{TiO}_{2} /$ graphene nanohybrids and application as counter electrode for dye-sensitized solar cells. ACS Appl. Mater. Interfaces 6, 2118-2124 (2014).

126 Wu, M., Bai, J., Wang, Y., Wang, A., Lin, X., Wang, L., Shen, Y., Wang, Z., Hagfeldt, A \& $\mathrm{Ma}, \mathrm{T}$. High-performance phosphide/carbon counter electrode for both iodide and organic redox couples in dye-sensitized solar cells. J. Mater. Chem. 22, 11121-11127 (2012).

127 Gong, F., Wang, H., Xu, X., Zhou, G. \& Wang, Z. S. In situ growth of $\mathrm{C}_{0.85} \mathrm{Se}$ and $\mathrm{Ni}_{0.85} \mathrm{Se}$ on conductive substrates as high-performance counter electrodes for dyesensitized solar cells. J. Am. Chem. Soc. 134, 10953-10958 (2012).

128 Guo, J., Shi, Y., Chu, Y. \& Ma, T. Highly efficient telluride electrocatalysts for use as Pt-free counter electrodes in dye-sensitized solar cells. Chem. Commun. 49 10157-10159 (2013). 
129 Roy-Mayhew, J. D., Bozym, D. J., Punckt, C. \& Aksay, I. A. Functionalized graphene as a catalytic counter electrode in dye-sensitized solar cells. ACS Nano 4, 6203-6211 (2010).

130 Wei, W. \& Hu, Y. H. Synthesis of carbon nanomaterials for dye-sensitized solar cells. Int. J. Energy Res. 39, 842-850 (2015).

131 Wei, W., Sun, K. \& Hu, Y. H. Synthesis of 3D cauliflower-fungus-like graphene from $\mathrm{CO}_{2}$ as a highly efficient counter electrode material for dye-sensitized solar cells. $J$. Mater. Chem. A 2, 16842-16846 (2014).

132 Wang, H. \& Hu, Y. H. Electrolyte-induced precipitation of graphene oxide in its aqueous solution. J. Colloid Interface Sci. 391, 21-27 (2013).

133 Wang, H. \& Hu, Y. H. Graphene as a counter electrode material for dye-sensitized solar cells. Energy Environ. Sci. 5, 8182-8188 (2012).

134 Wang, H., Leonard, S. L. \& Hu, Y. H. Promoting effect of graphene on dye-sensitized solar cells. Ind. Eng. Chem. Res. 51, 10613-10620 (2012).

135 Lee, K. S., Lee, H. K., Wang, D. H., Park, N. G., Lee, J. Y., Park, O. O. \& Park, J. H. Dye-sensitized solar cells with Pt-and TCO-free counter electrodes. Chem. Commun. 46, 4505-4507 (2010)
136 Yun, S., Zhang, H., Pu, H., Chen, J., Hagfeldt, A. \& Ma, T. Metal oxide/carbide/carbon nanocomposites: in situ synthesis, characterization, calculation, and their application as an efficient counter electrode catalyst for dye-sensitized solar cells. Adv. Energy Mater. 3, 1407-1412 (2013).

(c) (i) This work is licensed under a Creative Commons Attribution 4.0 International License. The images or other third party material in this article are included in the article's Creative Commons license, unless indicated otherwise in the credit line; if the material is not included under the Creative Commons license, users will need to obtain permission from the license holder to reproduce the material. To view a copy of this license, visit http:// creativecommons.org/licenses/by/4.0/ 